\title{
Moraine-dammed lake failures in Patagonia and assessment of outburst susceptibility in the Baker Basin
}

\author{
P. Iribarren Anacona ${ }^{1}$, K.P. Norton ${ }^{1}$, and A. Mackintosh ${ }^{1,2}$ \\ ${ }^{1}$ School of Geography Environment and Earth Sciences, Victoria University of Wellington, Wellington, New Zealand \\ ${ }^{2}$ Antarctic Research Centre, Victoria University of Wellington, Wellington, New Zealand \\ Correspondence to: P. Iribarren Anacona (pablo.iribarren@vuw.ac.nz)
}

Received: 11 July 2014 - Published in Nat. Hazards Earth Syst. Sci. Discuss.: 29 July 2014

Revised: 15 October 2014 - Accepted: 19 October 2014 - Published: 5 December 2014

\begin{abstract}
Glacier retreat since the Little Ice Age has resulted in the development or expansion of hundreds of glacial lakes in Patagonia. Some of these lakes have produced large $\left(\geq 10^{6} \mathrm{~m}^{3}\right.$ ) Glacial Lake Outburst Floods (GLOFs) damaging inhabited areas. GLOF hazard studies in Patagonia have been mainly based on the analysis of short-term series $(\leq 50$ years) of flood data and until now no attempt has been made to identify the relative susceptibility of lakes to failure. Power schemes and associated infrastructure are planned for Patagonian basins that have historically been affected by GLOFs, and we now require a thorough understanding of the characteristics of dangerous lakes in order to assist with hazard assessment and planning. In this paper, the conditioning factors of 16 outbursts from moraine-dammed lakes in Patagonia were analysed. These data were used to develop a classification scheme designed to assess outburst susceptibility, based on image classification techniques, flow routine algorithms and the Analytical Hierarchy Process. This scheme was applied to the Baker Basin, Chile, where at least seven moraine-dammed lakes have failed in historic time. We identified 386 moraine-dammed lakes in the Baker Basin of which 28 were classified with high or very high outburst susceptibility. Commonly, lakes with high outburst susceptibility are in contact with glaciers and have moderate $\left(>8^{\circ}\right)$ to steep $\left(>15^{\circ}\right)$ dam outlet slopes, akin to failed lakes in Patagonia. The proposed classification scheme is suitable for first-order GLOF hazard assessments in this region. However, rapidly changing glaciers in Patagonia make detailed analysis and monitoring of hazardous lakes and glaciated areas upstream from inhabited areas or critical infrastructure necessary, in order to better prepare for hazards emerging from an evolving cryosphere.
\end{abstract}

\section{Introduction}

Amongst the most frequent and damaging processes related to glaciers are Glacial Lake Outburst Floods (GLOFs). The failure of glacial lakes can release millions of cubic metres of water in a short time (minutes to days) and produce floods with high peak discharges $\left(10^{4} \mathrm{~m}^{3} \mathrm{~s}^{-1}\right)$ and remarkable erosive and transport capacity (Costa and Schuster, 1988; Breien et al., 2008). GLOFs can occur through different mechanisms. Moraine-dammed lakes commonly fail due to overtopping and the progressive enlargement of a breach in the dam. Rainfall, meltwater and waves produced by mass movements, ice avalanches or calving often trigger the overflow and subsequent moraine-dam failures (Costa and Schuster, 1988; Emmer and Cochachin, 2013). Piping after earthquakes, the mechanical failure of ice-cored moraines and flow waves from upstream lake failures have also been related to GLOFs (Lliboutry et al., 1977; Buchroithner et al., 1982).

In the Himalayas, European Alps and the Andes GLOFs have affected mountain communities for centuries, resulting in thousands of casualties (Hewitt, 1982; Grove, 1987; Reynolds, 1998). However, the generation of new glacial lakes as a consequence of glacier retreat, and the economic exploitation of previously uninhabited valleys make the emergence of new endangered areas likely. For example, in Chilean Patagonia, hydroelectric generation plants are being planned in areas that have historically been influenced by GLOFs (Dussaillant et al., 2009; Vince, 2010). Thus, there is now an urgent need to better understand and assess the GLOF hazard in these regions where detailed analyses are lacking. 


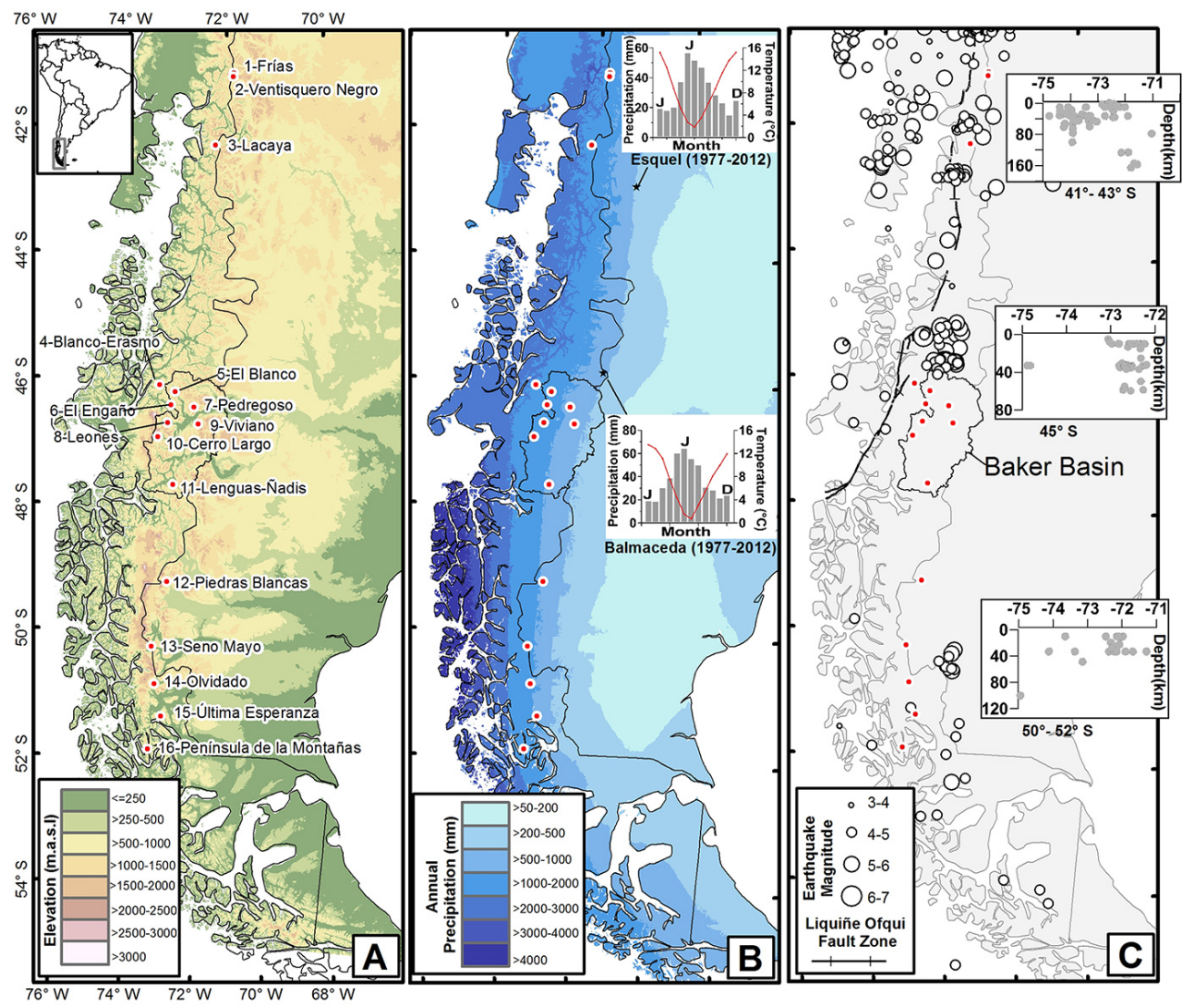

Figure 1. (a) Geographical setting and name (unofficial) of failed moraine-dammed lakes in Patagonia used to develop a GLOF susceptibility classification scheme. (b) Failed dams are located in zones with annual precipitation ranging from 500 to 2000 mm and where mean monthly temperature in winter is generally above $0^{\circ} \mathrm{C}$. (c) Note the decrease in the number and magnitude of earthquakes south of the $46^{\circ} \mathrm{S}$ and the high frequency of shallow earthquakes (hypocentre $<30 \mathrm{~km}$ ). Climate data extracted from Hijmans et al. (2005) and from the National Climatic Data Center (http://www.ncdc.noaa.gov). Seismic data (period 1973-2012) retrieved from the Northern California Earthquake Data Center (http://www.ncedc.org/anss/catalog-search.html).

A first step towards the analysis of GLOF hazards is the identification of glacier lakes. Remote sensing methods (e.g. image classification techniques) are especially suitable for this task allowing rapid analysis of large areas (hundreds of square kilometres) in an inexpensive way (Huggel et al., 2002; Kääb et al., 2005). Using these methods, hazardous lakes can be identified, and subsequently, if they are found to pose a potential risk to lives or infrastructure, more detailed local studies (e.g. GLOF modelling) might be developed (Mergili and Schneider, 2011) (e.g. Bajracharya et al., 2007; Worni et al., 2012). Hazardous lakes are identified by comparing lake characteristics (e.g. dam geometry and potential for ice avalanche impacts entering the lake) with those of failed lakes and their surroundings (McKillop and Clague, 2007; Bolch et al., 2011; Wang et al., 2011; Emmer and Vilímek, 2013). In Patagonia, data about failed morainedammed lakes have not been systematically analysed and the contributing factors of most of the failed moraine-dammed lakes are unknown.
Since the beginning of the 20th century, at least 16 moraine-dammed lakes have failed in Patagonia (Iribarren Anacona et al., 2014). Seven of these lakes are located in the Baker Basin where major hydroelectric generation plants are planned. One of these GLOFs (Laguna del Cerro Largo) is probably the largest outburst of a moraine-dammed lake (in terms of water volume released, $229 \times 10^{6} \mathrm{~m}^{3}$ ) reported worldwide (Hauser, 1993; Clague and Evans, 2000). In the Baker Basin GLOFs have destroyed houses, forced the relocation of a village and have damaged inhabitant's livelihoods (Iribarren Anacona et al., 2014). Furthermore, a flood wave with GLOF characteristics killed three people boating in the Baker River in January 1977 (El Diario de Aysén, 1977a, b). This makes the Baker Basin an important location to study the GLOF hazards.

In spite of the damage and the increasing frequency of GLOFs in Patagonia, and the Baker Basin, GLOFs hazards studies have been limited and based mainly on statistical analysis of short series ( $<50$ years) of flood data (HidroAysén, 2008; Vince, 2010). The relative susceptibil- 


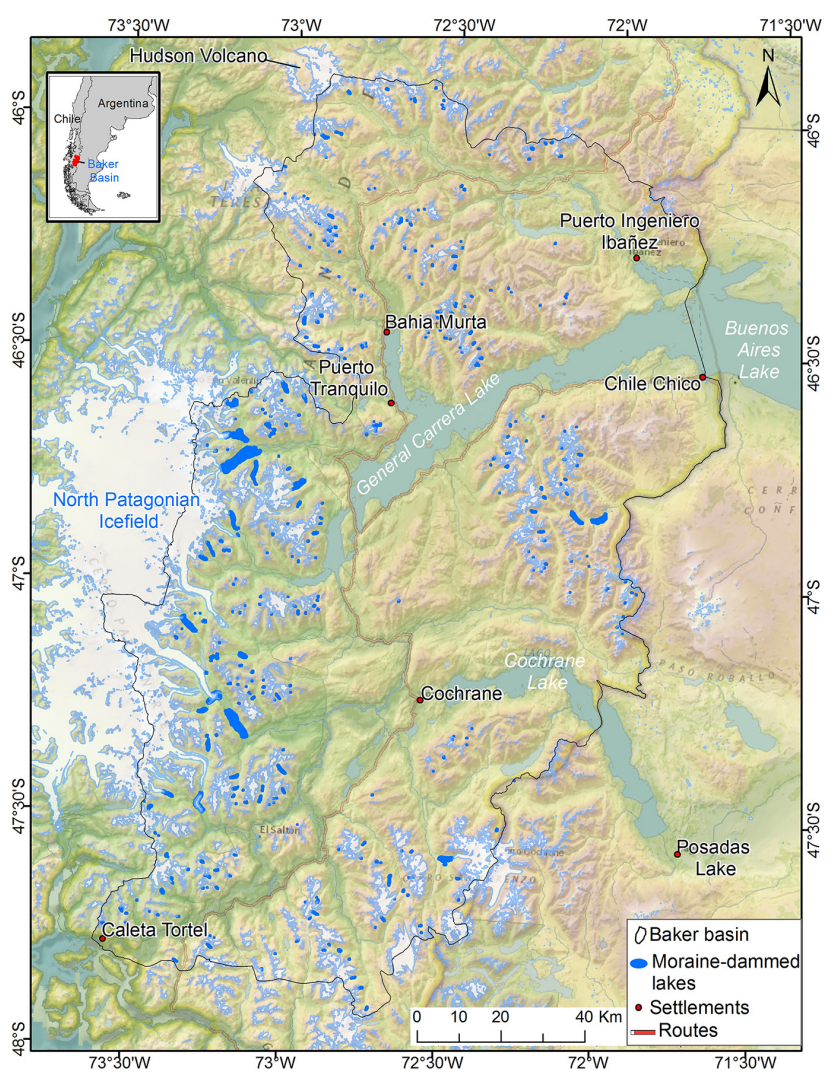

Figure 2. Location of moraine-dammed lakes and settlements in the Baker Basin.

ity to failure of moraine-dammed lakes in the Baker Basin is currently unknown as well as the extent to which these lakes pose a threat to infrastructure or human life.

In summary, GLOFs might pose a significant hazard to lives and newly developing infrastructure in Patagonia, but several questions remain unanswered concerning their past behaviour. The current status of moraine-dammed lakes, one of the prime sources of GLOFs, remains uncertain. We aim to analyse previously failed moraine-dammed lakes in Patagonia to identify the conditioning factors that led to failure, and to use these data to identify the moraine-dammed lakes most susceptible to future failure in the Baker Basin.

\subsection{Setting}

Patagonia is a region located in the southernmost part of South America $\left(\geq 40^{\circ} \mathrm{S}\right)$ in the territories of Chile and Argentina (Fig. 1). This region hosts some of the largest temperate ice masses on Earth (Harrison, 2011). However, glaciers in Patagonia have suffered significant losses in mass since the maximum Little Ice Age (LIA) expansion (between the 16th and 19th centuries) (Masiokas et al., 2009a), resulting in the formation or growth of several ice-, bedrock- and morainedammed lakes (Loriaux and Casassa, 2013). North-facing, land-terminating glaciers with surfaces $<5 \mathrm{~km}^{2}$ have shown the fastest retreat in the region (Davies and Glasser, 2012).

The Baker Basin is located between 46 and $48^{\circ} \mathrm{S}$, in the eastern side of North Patagonian Icefield (NPI) and has a surface area of about $20500 \mathrm{~km}^{2}$ of which ca. $1940 \mathrm{~km}^{2}$ are covered by ice (Fig. 2). Climate varies from arid continental, in the East (precipitation ca. $200 \mathrm{~mm}_{\text {year }}{ }^{-1}$ ) to maritime hyperhumid on the west side of the Andean main divide (precipitation ca. $2000 \mathrm{~mm}$ year $^{-1}$ ). Seismicity in the Baker basin is low. Seismic activity has been concentrated in the north associated with Hudson Volcano eruptions; however seismicity decreases south of $46^{\circ} \mathrm{S}$ (Barrientos, 2007) and no recent seismicity (from 1973 onwards) has been recorded in the rest of the basin. The Baker Basin is sparsely populated, mainly by low-density rural settlements. The number of tourists that visit the region is low (Muñoz et al., 2006). The basin hosts pristine rainforest, lakes and glaciers. Hundreds of glacier lakes exist in the Baker Basin where major hydroelectric schemes are planned. This makes the basin an ideal site to study the hazard posed by glacier lakes in Patagonia.

\section{Data and methods}

Data from historical outburst floods in Patagonia were used to develop an outburst susceptibility classification scheme which was applied in the Baker Basin. This section details the data used and procedures followed to (a) characterize the failed moraine dams in Patagonia (b) to select, measure and weight the outburst susceptibility factors and to (c) define the outburst susceptibility classes (Fig. 3).

\subsection{Data}

Morphometric characteristics of dams, glaciers and lake catchments were extracted from Landsat TM and ETM+ images. Both Landsat TM and ETM+ images have a spatial resolution of $30 \mathrm{~m}$ ( $15 \mathrm{~m}$ for the ETM+ panchromatic band) and were acquired from http://glovis.usgs.gov/. Topographic data were derived from the Advanced Spaceborne Thermal Emission and Reflection Radiometer Global Digital Elevation Model (ASTER GDEM V2). The spatial resolution of the ASTER GDEM V2 is 1 arcsecond (approximately $30 \mathrm{~m}$ ) and the DEM has a vertical accuracy of $17 \mathrm{~m}$ (Tachikawa et al., 2011).

\subsection{Characterization of failed moraine-dammed lakes in Patagonia}

The 16 moraine-dammed lakes that failed in historic time in Patagonia were mapped manually using Landsat images. In the oldest events (before 1985) the lake area and glacier extent prior to the outbursts were reconstructed using historical documents or geomorphic features (e.g. trimlines and lake shorelines). Morphometric parameters in these cases are less accurate than in GLOFs which occurred after 1985 but they 
Table 1. Data of 16 GLOFs in Patagonia and characteristics of the moraine-dammed lakes and their surroundings prior to the failure.

\begin{tabular}{|c|c|c|c|c|c|c|c|c|c|c|c|c|c|}
\hline \multirow[t]{2}{*}{ Site } & \multirow[t]{2}{*}{ Date } & \multicolumn{2}{|c|}{ Lake area $\left(\mathrm{km}^{2}\right)$} & \multirow[t]{2}{*}{$\mathrm{Ov}\left(\mathrm{m}^{3} \times 10^{6}\right)$} & \multirow[t]{2}{*}{$\operatorname{Pd}\left(\mathrm{m}^{3} \mathrm{~s}^{-1}\right)$} & \multirow[t]{2}{*}{$\mathrm{Pl}(\mathrm{km})$} & \multirow[t]{2}{*}{$\mathrm{H} / \mathrm{L}\left({ }^{\circ}\right)$} & \multirow[t]{2}{*}{$\mathrm{Dh}(\mathrm{m})$} & \multirow[t]{2}{*}{$\operatorname{Dos}\left({ }^{\circ}\right)$} & \multirow[t]{2}{*}{ Glc } & \multirow[t]{2}{*}{ Ias } & \multirow[t]{2}{*}{$\mathrm{Mms}$} & \multirow[t]{2}{*}{$\mathrm{Plg}$} \\
\hline & & Before & After & & & & & & & & & & \\
\hline 1. Gl. Frías & $1942-1953$ & 0.01 & 0 & 0.06 & 81 & - & - & $\leq 10 ?$ & 35 & $\mathrm{Y}(\mathrm{b})$ & $\mathrm{Y}$ & $\mathrm{Y}$ & $\mathrm{N}$ \\
\hline 2. Gl. Ventisquero Negro & 21 May 2009 & 0.55 & 0.32 & 4.36 & 1301 & 7.1 & 1.1 & 30 & 18 & Y & $\mathrm{N}$ & $\mathrm{Y}$ & $\mathrm{Y}$ \\
\hline 3. Río Lacaya & 2000-2001 & 0.33 & 0.15 & 3.14 & 1048 & 21.5 & 3 & $\leq 10 ?$ & 9 & $\mathrm{Y}$ & $\mathrm{Y}$ & $\mathrm{Y}$ & $\mathrm{N}$ \\
\hline 4. Monte Erasmo & $1985-2000$ & 0.71 & 0.69 & 0.16 & 150 & 6.0 & 2.1 & $\leq 10 ?$ & 8 & $\mathrm{Y}$ & $\mathrm{N}$ & $\mathrm{Y}$ & $\mathrm{Y}$ \\
\hline 5. Estero El Blanco & 2000-2003 & 0.12 & 0.04 & 1.05 & 511 & 5.4 & 5.1 & $\leq 10 ?$ & 11 & $\mathrm{~N}$ & $\mathrm{~N}$ & $\mathrm{Y}$ & $\mathrm{N}$ \\
\hline 6. Río Engaño & 11 Mar 1977 & 1.15 & 0.81 & 7.36 & 1839 & 6.5 & 2.1 & 50 & 24 & $\mathrm{Y}$ & $\mathrm{Y}$ & $\mathrm{Y}$ & $\mathrm{Y}$ \\
\hline 7. Estero El Pedregoso & 1985-1987 & 0.12 & 0.09 & 0.28 & 214 & 5.0 & 8.4 & - & 4 & $\mathrm{Y}(\mathrm{c})$ & $\mathrm{N}$ & $\mathrm{Y}$ & $\mathrm{Y}$ \\
\hline 8. Río Los Leones & 2000 & 0.02 & 0 & 0.16 & 150 & 2.3 & 7.4 & 40 & 22 & $\mathrm{~N}$ & $\mathrm{~N}$ & $\mathrm{Y}$ & $\mathrm{N}$ \\
\hline 9. Río Viviano & 1987-1998 & 0.02 & 0.01 & 0.06 & 81 & 2.3 & 7.3 & 15 & 26 & $\mathrm{~N}$ & $\mathrm{Y}$ & $\mathrm{Y}$ & $\mathrm{N}$ \\
\hline 10. Cerro Largo & 16 Mar 1989 & 1.82 & 0.98 & 24.73 & 4092 & 13.0 & 1.1 & 160 & 26 & $\mathrm{Y}$ & $\mathrm{Y}$ & $\mathrm{Y}$ & $\mathrm{N}$ \\
\hline 11. Estero Las Lenguas & 1987-1998 & 0.67 & 0.44 & 4.36 & 1301 & 23.8 & 1.3 & 110 & 21 & $\mathrm{Y}$ & $\mathrm{Y}$ & $\mathrm{Y}$ & $\mathrm{N}$ \\
\hline 12. Gl. Piedras Blancas & 16 Dec 1913 & 0.21 & - & - & - & 4.5 & 2.6 & 80 & 21 & $\mathrm{Y}$ & $\mathrm{Y}$ & $\mathrm{Y}$ & $\mathrm{Y}$ \\
\hline 13. Seno Mayo & 2001-2003 & 0.07 & 0.03 & 0.41 & 277 & 2.3 & 19 & $\leq 10 ?$ & 8 & $\mathrm{Y}$ & $\mathrm{N}$ & $\mathrm{Y}$ & $\mathrm{Y}$ \\
\hline 14. Gl. Olvidado & 2003 & 0.53 & - & - & - & 5.8 & 2.6 & 20 & 10 & $\mathrm{Y}$ & $\mathrm{N}$ & $\mathrm{Y}$ & $\mathrm{Y}$ \\
\hline 15. Última Esperanza & 1999-2006 & 0.09 & 0.08 & 0.06 & 81 & 10.6 & 4.0 & $\leq 10 ?$ & 5 & $\mathrm{Y}(\mathrm{c})$ & $\mathrm{Y}$ & $\mathrm{Y}$ & $\mathrm{Y}$ \\
\hline 16. Peninsula de las Montañas & 2005-2006 & 0.07 & 0.06 & 0.06 & 81 & 2.0 & 8.4 & $\leq 10 ?$ & 20 & $\mathrm{Y}$ & $\mathrm{N}$ & $\mathrm{Y}$ & $\mathrm{Y}$ \\
\hline
\end{tabular}

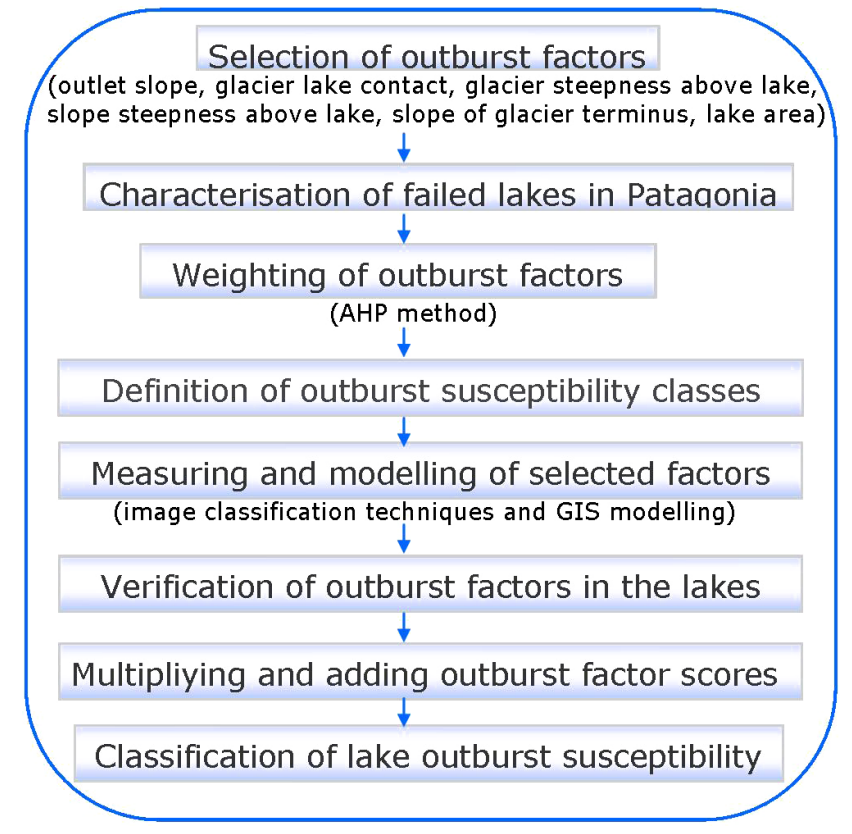

Figure 3. Flow chart of procedures followed to classify lake outburst susceptibility in the Baker Basin.

still provide an approximation of the lake and glacier conditions prior to the dam failures (Table 1). The basin and glacier topography were extracted automatically from the ASTER GDEM using standard spatial analysis tools (see Reuter and Nelson, 2008).

The GLOF paths were mapped on Landsat images and, when available, high-resolution satellite images $(\leq 5 \mathrm{~m})$ from Google Earth. GLOF angle of reach was measured along the flow path, from the dam breach to the lowest area of stripped vegetation or sediment deposition. Thus, path lengths may be underestimated in the oldest events due to vegetation re-

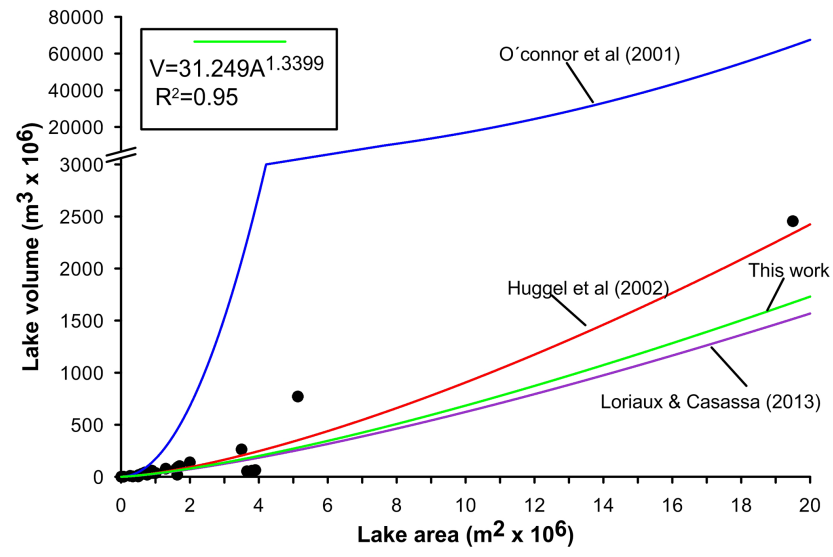

Figure 4. Empirical curves showing the relationship between area and volume of glacial lakes. The green curve was obtained from 38 data of lake area and volume of 25 moraine-dammed lakes worldwide. Note that the lake volume does not increase proportionally with an increase in the lake area and that the major divergence between curves occurs on the largest lakes where fewer data are available. Data extracted from O'Connor et al. (2001), Huggel et al. (2002), Allen et al. (2009), Rivas (2012) and Loriaux and Casassa (2013).

growth. The dam height and outlet slope were derived from topographic profiles drawn over the ASTER GDEM (30 m of spatial resolution) on undisturbed sections of the dam near the original lake outlet. Breaks in the topographic profile were not straightforward to map in the case of small dams (probably $\leq 10 \mathrm{~m}$ in height), making it difficult to estimate the dam geometry.

Lake volume and outburst peak discharges were calculated using empirical formulae. Several formulae exist that relate lake area and volume. Formulations by Huggel et al. (2002) and Loriaux and Casassa (2013) are based on data of ice- and 
moraine-dammed lakes, whereas the O'Connor et al. (2001) formula is based on a small number of moraine-dammed lakes. Ice- and moraine-dammed lakes often have different geometries (McKillop and Clague, 2007) and therefore different volumes. Thus, we collected data from literature of a large number of moraine dammed lakes worldwide (38 measurements of lake area and volume from 25 lakes; Fig. 4) and derived the following empirical formula to calculate lake volume:

$V=31.249 A^{1.3399}$,

where $V$ is the lake volume in $\mathrm{m}^{3} \times 10^{6}$ and $A$ is the lake area in $\mathrm{km}^{2}$.

We compared the measured volume of 38 data of moraine dammed lakes with the volume estimated with the derived empirical formula. The mean error of the volume estimates was $\pm 71 \%$.

The peak discharge was calculated using the following formula proposed by Walder and O'Connor (1997):

$Q=0.054 V^{0.66}$,

where $V$ is the lake volume in $\mathrm{m}^{3}$.

Outburst parameters estimated by regression-based methods have large uncertainty. Dam breach peak discharge estimates can have uncertainties of up to \pm 1 order of magnitude (Wahl, 2004).

\subsection{Selection of outburst susceptibility factors}

Lakes dammed by temperate glaciers may be considered inherently unstable since ice-dam characteristics (e.g. glacier thickness, crevassing and bed adhesion) are subject to frequent changes, affecting the ice-conduit dynamics (Tweed and Russell, 1999). Consequently, we considered all the icedammed lakes as hazardous. Thus, we centred our analysis on selecting variables to identify moraine-dammed lakes susceptible to failure. Several variables have been used to identify hazardous moraine-dammed lakes (see Emmer and Vilímek's, 2013, review paper). The dam geometry (e.g. width-to-height ratio, flank steepness and dam freeboard) and internal structure (e.g. presence of ice and particle size distribution) are probably the most important conditioning factors of outburst floods (Richardson and Reynolds, 2000a). However, most dam characteristics can only be measured accurately in the field or by using high-resolution satellite images or DEMs. We chose six characteristics of lakes, dams and their surroundings that can be measured and modelled using medium-resolution satellite images and DEMs. These variables comprise outburst conditioning and triggering factors and also give an idea of the outburst damaging potential. Due to the low spatial and temporal resolution of meteorological data in Patagonia, extreme meteorological events were not included in the analysis. The selected outburst factors are described below.

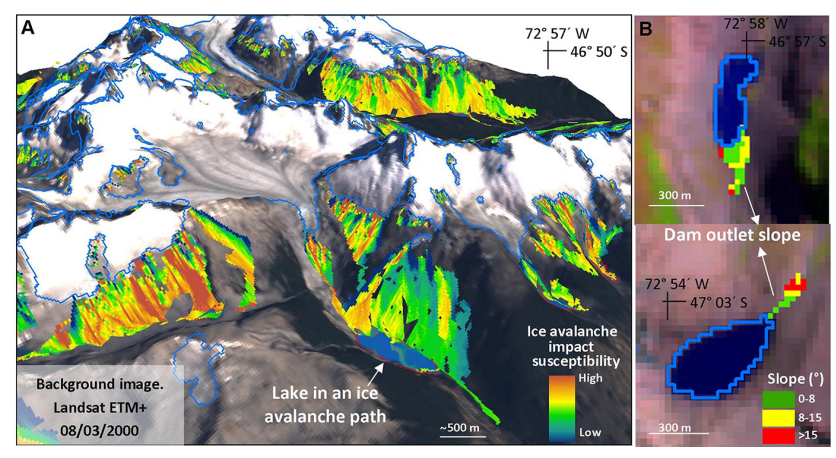

Figure 5. (a) Results of ice avalanche modelling and automatic classification of glaciers. (b) Examples of lake outlet slope measurements.

\subsubsection{Lake area}

Lake dimensions have been directly related to outburst volume, peak discharge and the flood damage potential (Costa and Schuster, 1988). Accordingly, larger lakes are considered to be more hazardous than small lakes. Furthermore, lakes with larger areas are generally deeper (see e.g. Diaz et al., 2007 database), and may exert higher hydrostatic pressures over the dams making them more susceptible to failure (Richardson and Reynolds, 2000b). Larger lakes also have a greater surface area potentially exposed to mass movement and ice avalanche impacts, increasing their outburst susceptibility.

\subsubsection{Glacier-lake contact}

Lakes in contact with glaciers can be affected by calving and the sudden floating of dead ice. Both mechanisms can produce waves capable of overtopping dams starting a breaching process and subsequent dam failure (Richardson and Reynolds, 2000a). Icebergs also can block the lake outlet, raising the water level potentially overtopping and breaching the dam. Thus, lakes in contact with glaciers are considered more hazardous than lakes detached from the glacier snout.

\subsubsection{Slope of glacier terminus}

A glacier with a low-angle terminus can be an indicator of a negative mass balance. Consequently, lakes in contact with flat glacier fronts (slopes less than $5^{\circ}$ ) are likely to grow as a consequence of glacier retreat (Frey et al., 2010a). Lakes that are expected to grow are more hazardous than lakes which are expected to remain stable or shrink (examples of minor moraine dammed lake area reduction, not related to GLOFs, have been observed in Patagonia; see Fig. 5d in Loriaux and Casassa, 2013), since the potential area exposed to mass movements or ice avalanches may increase and the dams may be subject to higher hydrostatic pressures. 


\subsubsection{Lake outlet slope}

Steep outlets can be more easily enlarged than low-gradient outlets if an increase in the lake discharge occurs. Progressive erosion can widen and deepen the outlet leading to lake drainage. Consequently, dams with steep outlets are more susceptible to failure (O'Connor et al., 2001). Furthermore, high dams which produce outbursts with high peak discharges (Walder and O'Connor, 1997) usually have steep outlets (see Table 1).

\subsubsection{Glacier steepness above lake}

Steep $\left(\geq 25^{\circ}\right)$ temperate glaciers are a common source of ice avalanches (Alean, 1985). Ice avalanches impacting lakes can generate impulse waves capable of overtopping dams starting catastrophic lake drainage. The likelihood of an ice avalanche impacting a lake depends on the distance, slope and roughness of the terrain between the glacier and the water body. Ice avalanches are the most common cause of outburst floods in the Himalayas (Wang et al., 2011) and have also been reported in the Tropical Andes (Lliboutry et al., 1977).

\subsubsection{Steepness of slopes above lake}

Steep unvegetated slopes are a common source of mass movements (Peduzzi, 2010) and can be indicators of high geomorphic activity. Large and high-velocity landslides can generate impulse waves of hundreds of metres of run-up that can easily overtop dams starting progressive erosion and lake drainage (Walder et al., 2003). Lakes can also be suddenly drained by large waves without a dam-breaching process (Clague and Evans, 2000). Mass movement impacts have been related to outburst floods in Patagonia and other Andean regions (Hubbard et al., 2005; Harrison et al., 2006).

\subsection{Measuring and modelling of selected factors}

\subsubsection{Glacier and lakes delimitation}

Glaciers and lakes were delimited using multispectral classification techniques that exploit the maximum reflectance difference of a surface (i.e. glaciers and lakes) in different spectral channels to identify the desired object (Huggel et al., 2002; Paul et al., 2002). Thresholded band ratios have been successfully used in glacier inventories (e.g. Andreassen et al., 2008; Svoboda and Paul, 2009). We mapped glaciers via band rationing of the near-infrared and mid-infrared bands of Landsat images in reflectance values (i.e. pixel values not converted to radiance; Paul et al., 2002). The thresholds values to identify glaciers (bare ice) were defined comparing visually the band ratio image with false composite Landsat images (Table 2). Debris-covered glaciers were drawn manually.
Lakes in the Baker Basin were mapped using the Normalized Difference Water Index (NDWI) of Huggel (2002) obtained from the following equation:

NDWI $=($ Near-Infrared Band - Blue Band $)$

$$
\text { /(Near-Infrared Band + Blue Band). }
$$

The NDWI was applied on Landsat images in Digital Numbers. A cast-shadow mask was used to eliminate shadowy areas mistakenly classified as lakes (see Huggel et al., 2002).

A median filter of $3 \times 3$ kernels was applied to smooth the glacier and lake surfaces incorporating or eliminating isolated pixels in the classified image (Paul et al., 2002). Misclassified lakes in shadowy areas and debris-covered glaciers were corrected manually. The error in lake and glacier delimitation is estimated to be one pixel (i.e. $\pm 30 \mathrm{~m}$ ) although it can be larger in shadowy areas. The lake inventory was developed using images from the years 2000 and 2002. However, Landsat images of the years 2012 and 2013 also were analysed to manually incorporate recently formed lakes in the inventory and to assess the glacier-lake contact status. Only the area of lakes in contact with glaciers was determined using 2012-2013 images since the area of other lakes probably remained stable (see Loriaux and Casassa, 2013). The 20122013 images were not used as base for the entire inventory since about $20 \%$ of the data in each Landsat 7 image were lost after the failure of the scan-line corrector in May 2003 (USGS et al., 2003). Google Earth images were used to classify the dams (i.e. moraine, bedrock or ice dams). Only lakes located in valleys glaciated during the LIA were included in the analysis since lakes situated far from the LIA expansion (including very large moraine-dammed lakes such as General Carrera and small lakes dammed by bedrock) were considered to be stable. Published geomorphological maps were used to identify the glacier extent during LIA (Glasser et al., 2011; Glasser and Jansson, 2008), which was also inferred from trimlines and terminal moraines.

\subsubsection{Slope steepness above lake and mass movement modelling}

Mass movement paths were mapped using the Modified Single Flow Direction (MSF) model of Huggel et al. (2003). The MSF simulates the trajectory of mass movements from the source area following the steepest descent with a maximum deviation of $45^{\circ}$. The mass movement stops (i.e. the end of the path) when it reaches a predetermined ending condition generally set as the angle of reach (i.e. the angle of the line connecting the starting and the ending zone of a mass movement; Hsu, 1975) (see Huggel et al., 2003 and Gruber et al., 2008 for model details).

Published data of the angle of reach of mass movements and typical angles of detachment zones were used as input to model the flow paths. The angle of reach and the slope of the starting zone of rock falls, debris flows and other complex mass movements vary locally according to the geol- 
Table 2. Satellite images and threshold used to identify glaciers, lakes and vegetation.

\begin{tabular}{lrrrrr}
\hline Sensor & Image date & Path/row & $\begin{array}{r}\text { Glacier band } \\
\text { ratio threshold } \geq\end{array}$ & $\begin{array}{r}\text { Lakes NDWI } \\
\text { threshold } \geq\end{array}$ & $\begin{array}{r}\text { Vegetation NDVI } \\
\text { threshold } \geq\end{array}$ \\
\hline \multirow{3}{*}{ Landsat ETM+ } & & 3 & -0.5 & 0.1 \\
& 8 Mar 2000 & $232 / 092$ & & & - \\
& & & & & - \\
& 18 Feb 2013 & $232 / 092$ & 2.5 & -0.45 & - \\
18 Feb 2002 & $231 / 093$ & $231 / 092$ & 1.5 & -0.45 & - \\
8 Mar 2000 & $232 / 093$ & 3 & -0.5 & - \\
22 Feb 2012 & $232 / 093$ & - & - & -1 \\
\hline
\end{tabular}

Table 3. Pairwise comparison of outburst predictor variables and consistency ratio.

\begin{tabular}{lrrrrrr}
\hline Matrix & $\begin{array}{r}\text { Glacier-lake } \\
\text { contact }\end{array}$ & $\begin{array}{r}\text { Lake } \\
\text { area }\end{array}$ & $\begin{array}{r}\text { Glacier steepness } \\
\text { above lake }\end{array}$ & $\begin{array}{r}\text { Slope steepness } \\
\text { above lake }\end{array}$ & $\begin{array}{r}\text { Slope of } \\
\text { glacier terminus }\end{array}$ & $\begin{array}{r}\text { Lake outlet } \\
\text { slope }\end{array}$ \\
\hline Glacier-lake contact & 1 & 2 & 2 & 2 & 3 & 1 \\
Lake area & $1 / 2$ & 1 & $1 / 2$ & 2 & 2 & $1 / 3$ \\
Glacier steepness above lake & $1 / 2$ & 2 & 1 & 3 & 3 & $1 / 2$ \\
Slope steepness above lake & $1 / 2$ & $1 / 2$ & $1 / 3$ & 1 & 2 & $1 / 3$ \\
Slope of glacier terminus & $1 / 3$ & $1 / 2$ & 2 & 3 & 5 \\
Lake outlet slope & 1 & 3 & 2 & $1 / 3$ & 1 \\
\hline
\end{tabular}

Consistency ratio: 0.026

Factor intensity: 1: Equal importance; 3: Moderate prevalence of one over another; 5: Strong or essential prevalence; 7: Very strong or demonstrated prevalence; 9 : Extremely high prevalence; 2, 4, 6 and 8: express intermediate values (after Saaty and Vargas 2001).

ogy, terrain roughness and vegetation coverage. Steep unvegetated slopes may indicate high geomorphic activity and can be associated with loose, readily erodible material. Thus, we assume potential starting zones for all mass movements are unvegetated or sparsely vegetated slopes $\geq 30^{\circ}$. We have not distinguished between solid bedrock slopes and noncohesive slopes since this task can only be accurately accomplished by photo interpretation or fieldwork, which are costly or time consuming, and consequently not suited to our preliminary regional analysis.

Vegetation was mapped using the Normalized Vegetation Index (NDVI) calculated using the following equation:

$$
\begin{aligned}
\text { NDVI }= & (\text { Near-Infrared Band }- \text { Red Band }) \\
& /(\text { Near-Infrared Band }+ \text { Red Band }) .
\end{aligned}
$$

The angle of reach of mass movements was considered similar to that of rock avalanches (about $15^{\circ}$; see Nicoletti and Sorriso-Valvo, 1991) which are the events most likely to start catastrophic lake drainages.

\subsubsection{Glacier steepness above lake and ice avalanche modelling}

The ice avalanche paths were also delineated using the MSF model based on empirical data of ice avalanches source and angle of reach (Fig. 5). According to Alean (1985) ice avalanches commonly start at slopes $\geq 25^{\circ}$ in temperate glaciers (such as Patagonian glaciers) and have an angle of reach of $17^{\circ}$ (data derived from about 100 ice avalanches mostly from the European Alps). Thus, we mapped glacier surfaces with slopes $\geq 25^{\circ}$ and used these areas as ice avalanche detachment zones. The stopping condition in the MSF model was set at an angle of reach of $17^{\circ}$.

\subsubsection{Lake outlet slope measurement}

The lake outlet and the outlet slope were identified and measured automatically following a series of GIS procedures. First, we identified the lake outlet as the point with maximum flow accumulation in the lake (see Gruber and Peckham, 2008). From this point the steepest descent path 200 metres downstream (with a maximum deviation of $45^{\circ}$ ) was calculated using the Path Distance tool of ArcGIS. We assumed that moraine-dam widths are less than $200 \mathrm{~m}$. Dam widths of the largest failed lakes in Patagonia are $\geq 300 \mathrm{~m}$. However, we used a smaller value since most of the morainedammed lakes in the Baker Basin are small and this value $(200 \mathrm{~m})$ does not significantly affect the average slope of larger dams. Finally, the mean slope of the steepest descent path was calculated. 
Table 4. Weight of variables associated with moraine-dammed lake failures.

\begin{tabular}{|c|c|c|c|c|c|c|c|c|c|c|c|}
\hline \multicolumn{12}{|c|}{ Variable weight } \\
\hline \multicolumn{2}{|c|}{$\begin{array}{l}\text { Lake outlet } \\
\text { slope } \\
30\end{array}$} & \multicolumn{2}{|c|}{$\begin{array}{l}\text { Glacier-lake } \\
\text { contact } \\
25\end{array}$} & \multicolumn{2}{|c|}{$\begin{array}{c}\text { Glacier steepness } \\
\text { above lake } \\
18\end{array}$} & \multicolumn{2}{|l|}{$\begin{array}{c}\text { Lake area } \\
12\end{array}$} & \multicolumn{2}{|c|}{$\begin{array}{c}\text { Stability of slopes } \\
\text { above lake* } \\
9\end{array}$} & \multicolumn{2}{|c|}{$\begin{array}{c}\text { Slope of } \\
\text { glacier terminus } \\
6\end{array}$} \\
\hline \multicolumn{12}{|c|}{ Classes weight } \\
\hline$\geq 15^{\circ}$ & 1 & Yes & 1 & $\geq 25^{\circ}$ & 1 & $>0.5 \mathrm{~km}^{2}$ & 1 & Yes & 1 & Yes & 1 \\
\hline$\geq 8^{\circ}$ and $<15^{\circ}$ & 0.75 & No & 0 & $<25^{\circ}$ & 0 & $>0.1$ to $0.5 \mathrm{~km}^{2}$ & 0.75 & No & 0 & No & 0 \\
\hline$<8^{\circ}$ & 0 & & & & & 0.01 to $0.1 \mathrm{~km}^{2}$ & 0.5 & & & & \\
\hline
\end{tabular}

\subsection{Weighting process}

After analysing 16 GLOFs in Patagonia, the six conditioning factors were weighted using the Analytical Hierarchy Process (AHP) (Saaty, 1980). We chose this method since it allows evaluation of the consistency of the subjective judgements which is not accomplished by other qualitative or semi-quantitative GLOF hazard approaches (see Emmer and Vilímek, 2013, for a review). The AHP is a multicriteria decision-making technique which allows estimation of the relative significance of factors contributing to an event based on pairwise comparison, expert judgment and the linear algebra transformation of the comparison factors matrix (Table 3). The aim of the pairwise comparison is to assess the significance of one factor compared to another. Values from 1 to 9 can be assigned to each factor, where a value of 1 means that both factors have equal importance and a value of 9 means that a factor has an extreme prevalence over another.

The AHP method has been used in natural hazard assessments by several authors (e.g. Ayalew et al., 2005; Lari et al., 2009). The AHP also allows the evaluation of the consistency of the judgements based on the estimation of the eigenvalue of the factors matrix. Generally only consistency ratios $<0.1$ are considered acceptable (Satty, 1980). We assigned the higher weights to the GLOF factors more frequently associated with GLOFs in Patagonia. After weighting the six GLOF factors, each factor was subdivided into classes for which we assigned weights (Table 4). The total GLOF susceptibility score for each lake was obtained by multiplying the weight of the factor by the weight of the classes and then adding up the six factor scores. The highest possible score is 100.

To define the outbursts susceptibility classes we applied the outburst classification scheme to the failed lakes in Patagonia. Five categories that represent five relative scales of outburst susceptibility were defined (Fig. 6). Twelve (75\%) of the 16 recorded failed lakes in Patagonia had scores $\geq 65$. Thus, a score of 65 was used as threshold to classify lakes with high outburst susceptibility.

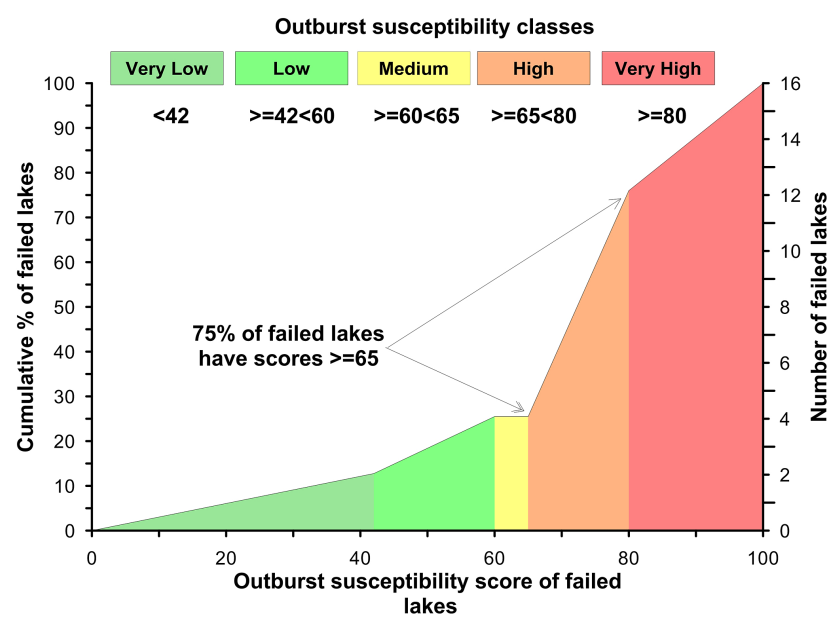

Figure 6. Outburst susceptibility score of the 16 moraine-dammed lakes failed in Patagonia. These data were used to define five outburst susceptibility classes.

\section{Results}

This section summarizes characteristics of moraine-dammed lakes failed in Patagonia. The data provide insights to identify moraine-dammed lakes with high outburst susceptibility in the region.

\subsection{Characteristics of GLOFs, failed lakes and their surroundings}

\subsubsection{GLOFs characteristics}

Moraine-dammed lakes that failed in historic time in Patagonia had areas ranging from 0.01 to $1.82 \mathrm{~km}^{2}$ (Table 1). Fourteen lakes experienced just a partial emptying; including the largest lake (Laguna del Cerro Largo) which released an estimated water volume of $\sim 229 \times 10^{6} \mathrm{~m}^{3}$ (Hauser, 2000). The outburst paths (patches of stripped vegetation and/or debris deposition visible in Landsat images) range from few kilometres up to $\sim 27 \mathrm{~km}$ in length and commonly are less than $100 \mathrm{~m}$ wide. However, GLOFs probably reached farther ar- 


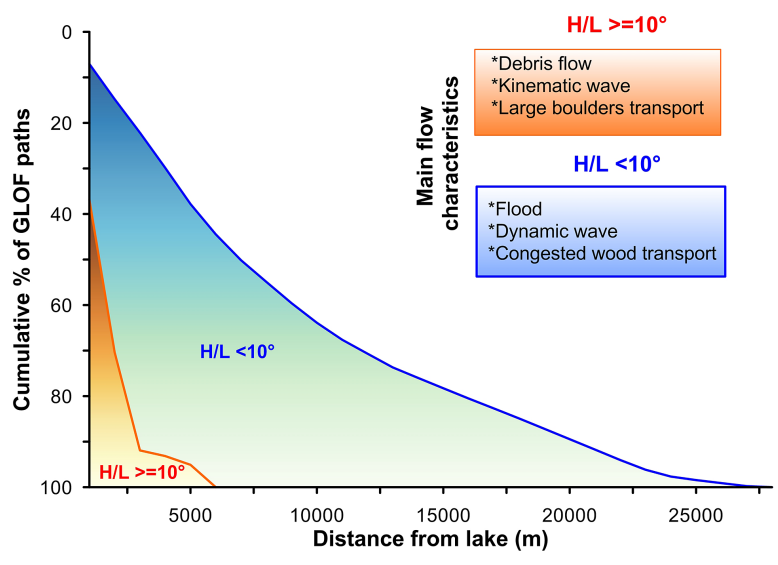

Figure 7. Accumulated percentage of GLOF paths within different angles of reach $\left(\mathrm{H} / \mathrm{L}\right.$ ). Most path sections with $\mathrm{H} / \mathrm{L} \geq 10^{\circ}$ (where debris flows often occur) are located at distances $\leq 3000 \mathrm{~m}$ from failed lakes. Sections with $\mathrm{H} / \mathrm{L} \leq 10^{\circ}$ ( $89 \%$ of the total path lengths) often have diffusive and rapidly attenuating flows. H/L was measured every $10 \mathrm{~m}$ from 15 failed moraine-dammed lakes in Patagonia.

eas since vegetation recovery might conceal evidence of flow after just a few years. This has been corroborated by eyewitness's accounts (interviews held by the authors with inhabitants of Los Leones valley and Bahía Murta Village) which indicate that floating debris (large trees) were transported during GLOFs to the river outlets, kilometres from the preserved geomorphic evidence, clearly posing a risk for inhabited areas. GLOF paths are dominated by steep slopes up to five kilometres from the lakes (Fig. 7). These sections of the GLOF paths favour the development of debris flows and the transport of coarse material from failed dams. In the lowest areas, patches of stripped vegetation and bank erosion are common, although the flows attenuate due to wider valleys and lower slopes.

\subsubsection{Dam characteristics}

Outbursts have affected moraine dams with different geometries. Drained lakes were dammed by both, steep moraine arcs and relatively flat ground moraines. No relationship between moraine heights and failure was evident, although higher dams (associated with larger lakes) resulted in GLOFs with higher peaks discharges. The heights of the failed dams vary from a few metres to up to $160 \mathrm{~m}$. In eight cases the dams were small making it difficult to accurately estimate their dimensions. However, they were probably $\leq 10 \mathrm{~m}$ high. Nine dams were vegetated at the time of failure and one of them (Piedras Blancas) was covered by mature forest dating from the early 1600s (Masiokas et al., 2009b). Most of the failed lakes had moderate to steep outlet slopes. The outlet slope of 14 lakes was $\geq 8^{\circ}$ and 8 lakes had outlet slopes $\geq 5^{\circ}$. The dam's internal composition is known in just one case. The Ventisquero Negro dam was composed of noncohesive coarse material (boulders and blocks) in a matrix of

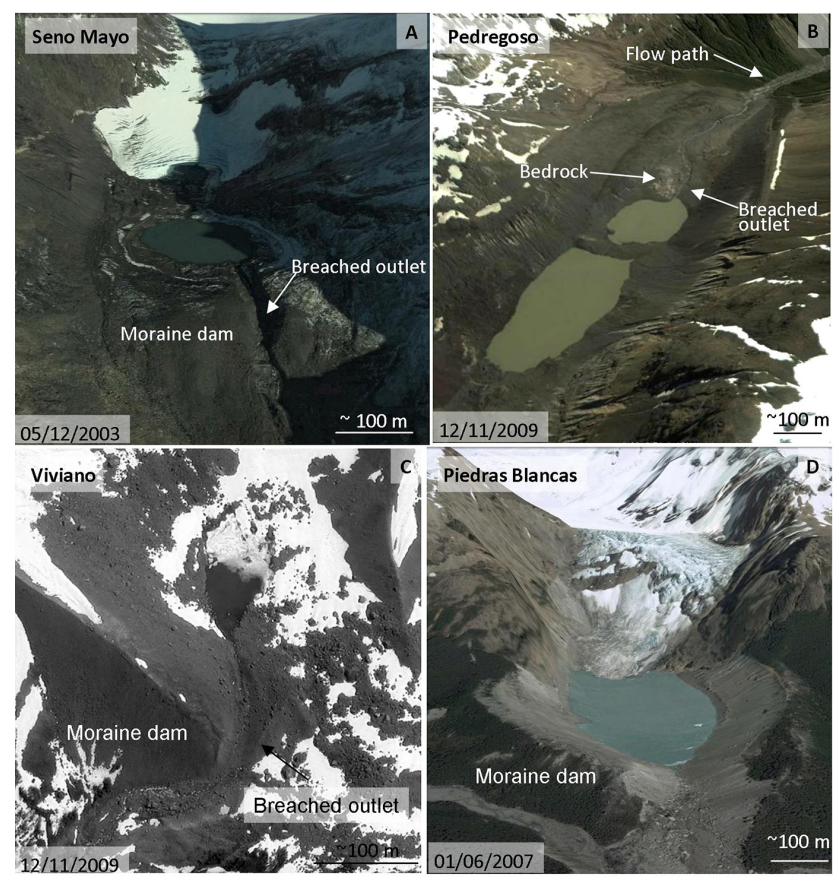

Figure 8. Types of moraine dams failed in Patagonia; (a) lake perched over moraine deposits (b) lake dammed by ground moraines and partially by bedrock (c) lake dammed by a small crestshaped dam and (d) lake behind large and steep vegetated dam. Images sourced from Google Earth.

sand and gravel. This dam was vegetated and also presented an ice-core at the time of failure (Worni et al., 2012). Estero el Pedregoso Lake was dammed by (or was embedded in) glaciofluvial deposits and was partially dammed by bedrock (Fig. 8).

\subsubsection{Characteristics of upstream catchments}

Moraine-dammed lakes that produced outburst floods in Patagonia were located in different settings. Thirteen lakes were in contact with a glacier at the time of failure and in at least three cases (Ventisquero Negro, Olvidado and Península de las Montañas) glaciers exhibited rapid retreat before the outburst floods (Fig. 9). For example, between 2000 and 2003 the Olvidado Glacier retreated $271 \mathrm{~m}$ per year (Rivera and Casassa, 2004) significantly increasing the lake surface before the failure. Half of the lakes were located in areas prone to ice avalanches. In fact, the upper-edge of Lacaya and Las Lenguas lakes were at the toe of reconstituted glaciers, clear indicators of high snow and ice avalanche activity (Fig. 9). All of the lakes were surrounded by steep $\left(\geq 25^{\circ}\right)$ valley walls or moraines. Rock-falls, snow avalanches and debris flows are common in this setting. However, a mass movement was definitely identified as the cause of the dam failure in just one case (see Harrison et al., 2006). In the other cases (excluding Piedras Blancas and Frías outbursts) no evidence of large mass movements (i.e. fresh landslide scars 

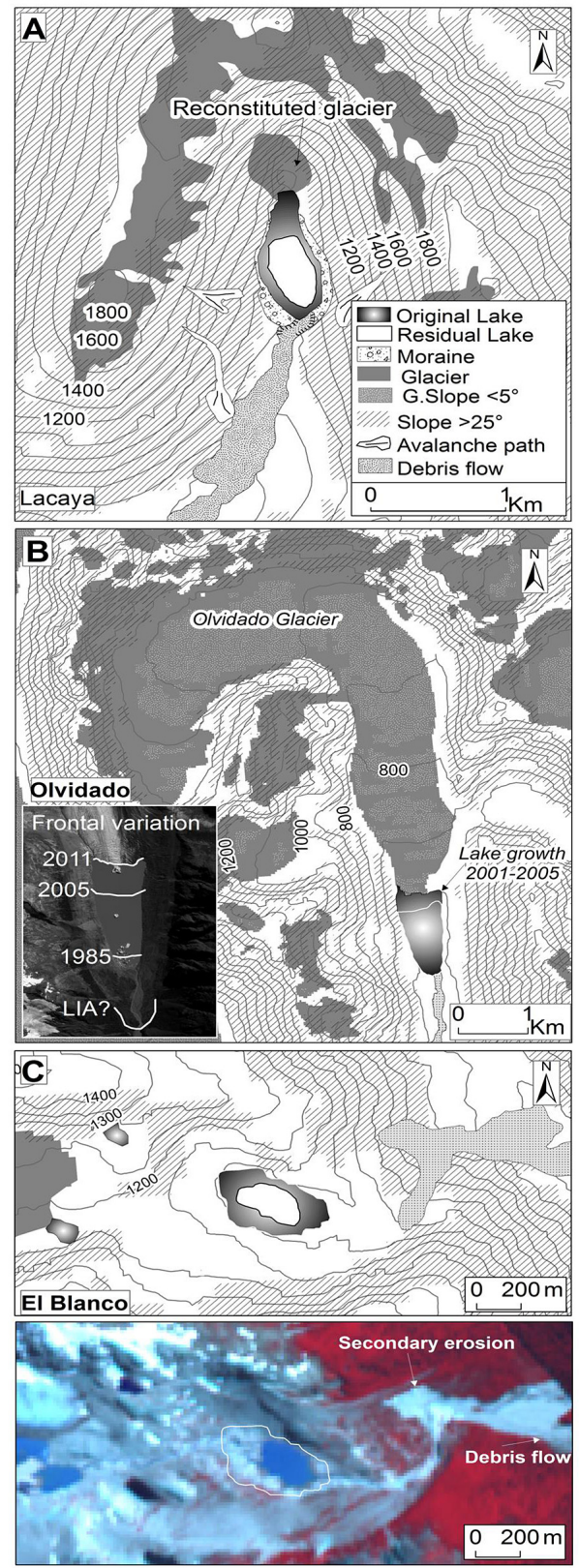

Figure 9. Settings of moraine-dams failed in Patagonia; (a) lake in the head of a catchment at the toe of a reconstituted glacier, (b) growing lake in contact with a retreating glacier and (c) lake distant from the glacier tongue. Note the steep slopes and glaciers surrounding the lakes.

or deposits) in the lake's surroundings were identified when comparing images before and after the outburst floods.

\subsubsection{Triggering factors}

The triggering of only 3 of the 16 GLOFs is known. However, these events exemplify the variety of factors that can cause outburst floods. These factors include gravitational processes and meteorological events. The outburst of the Calafate Lake in the Río Los Leones Valley was caused by the impact of a rock-fall into the lake. The rock-fall detached from a recently deglaciated slope and completely covered the lake's area (Harrison et al., 2006) generating impact waves that probably caused an almost instantaneous lake emptying. The Río Engaño outburst was caused by a different gravitational process. Reconnaissance flights carried out few days after the Río Engaño outburst indicate that the lake was impacted by glacier ice (this might correspond to an ice avalanche or calving) that probably caused waves which overtopped the dam and started the lake drainage (El Diario de Aysén, 1977c). The Ventisquero Negro outburst occurred after prolonged $(180 \mathrm{~mm}$ of rain in 6 days) and intense $(50 \mathrm{~mm}$ of rain in the $48 \mathrm{~h}$ prior the outburst) rainfall that possibly caused an overflow and subsequent dam breach and failure (Worni et al., 2012).

\subsection{Glacial lakes in the Baker Basin}

Overall, 480 glacial lakes with surfaces $\geq 0.01 \mathrm{~km}^{2}$ were identified in the Baker Basin. Distinguishing between bedrock and moraine-dammed lakes proved to be difficult. All uncertain cases $(<10 \%)$ were classified as morainedammed lakes in order to evaluate their outburst susceptibility. A preliminary classification indicated that 85 lakes are dammed by bedrock and $386(80 \%)$ lakes are dammed by moraines. Only three lakes are dammed by glaciers. Two of them are dammed by the Colonia Glacier, the Lake Cachet 2 (drained 10 times between 2008 and 2012) and a smaller $\left(0.35 \mathrm{~km}^{2}\right)$ unnamed lake located $10 \mathrm{~km}$ to the north. A fourth ice-dammed lake (Laguna Bonita) emptied at least two times between 2002 and 2008. However, glacier retreat since the last outburst now impedes the lake refilling (Iribarren Anacona et al., 2014). Of the 386 moraine-dammed lakes at least seven have produced outburst floods.

\subsubsection{Lake outburst susceptibility in the Baker Basin}

According to our classification scheme, the majority of the moraine-dammed lakes in the Baker Basin have low outburst susceptibility. The lakes have low-gradient outlets, are disconnected from glaciers or are small $\left(<0.1 \mathrm{~km}^{2}\right)$ (Fig. 10). However, such lakes may still produce outburst floods as they are subject to ice avalanches or mass movement impacts. Seven moraine-dammed lakes are in the range of very high outburst susceptibility and 21 lakes are in the range of high outburst susceptibility (Fig. 6). A closer look of these lakes, however, shows that the largest lakes are located in flat valleys and have superficial drainage through large (several metres) low-gradient outlets making a catastrophic lake drainage unlikely. This is the case for example of the Fiero, Laguna Soler and Cachet 1 lakes. While these lakes are exposed to ice avalanches or mass movements, impact waves may be attenuated after travelling long distances (Slinger- 

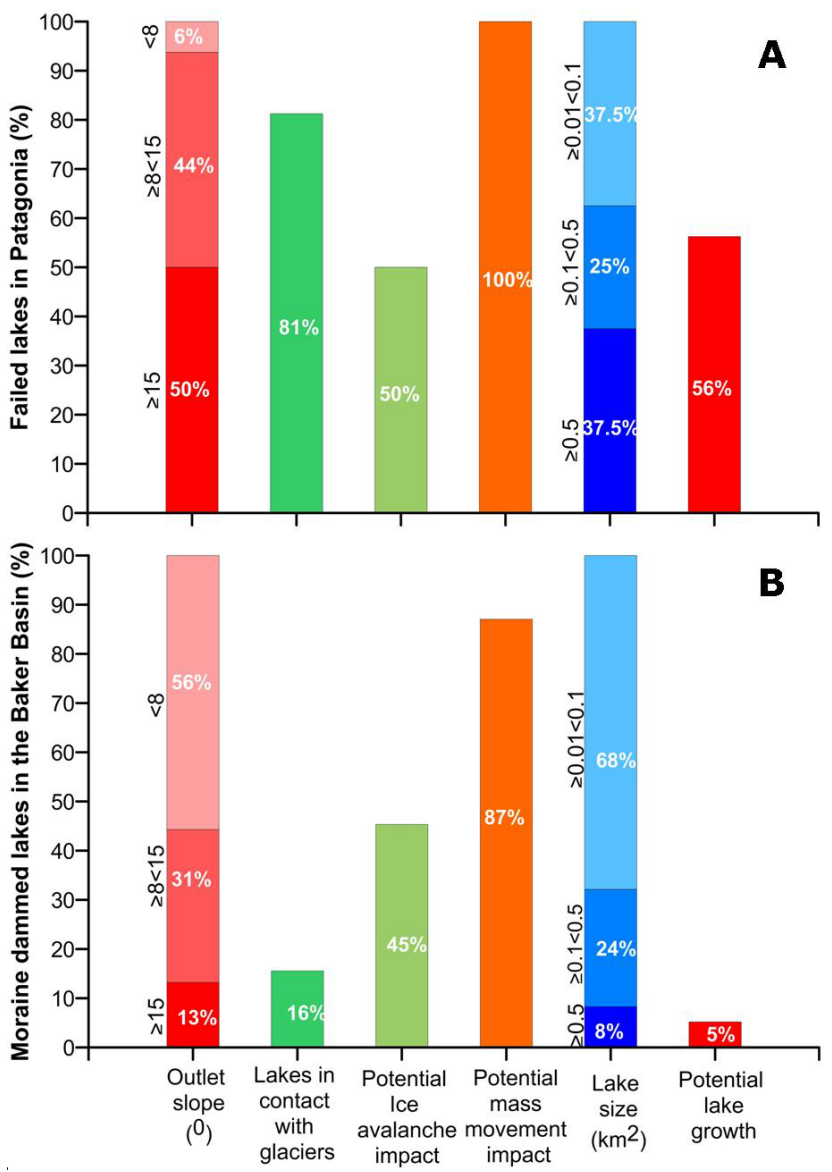

Figure 10. (a) Characteristics of 16 failed moraine-dammed lakes in Patagonia and (b) characteristics of 386 moraine-dammed lakes in the Baker Basin.

land and Voight, 1979), reducing the outburst susceptibility. Low-gradient outlets also limit the transformation of eventual outburst floods into debris flows since this phenomenon generally starts in slopes $\geq 10^{\circ}$ (Hungr et al., 1984). Smaller lakes with high or very high outburst susceptibility which are in the surface range $\left(\leq 1.82 \mathrm{~km}^{2}\right)$ of failed lakes in Patagonia more closely resemble their characteristics (i.e. lakes with steep outlet slopes in contact with glaciers and exposed to ice avalanches and mass movements) (Fig. 11). The computed (hypothetical) peak discharge of GLOFs from the 28 lakes most susceptible to failure range from 70 to more than $10000 \mathrm{~m}^{3} \mathrm{~s}^{-1}$ in the worst scenario $(100 \%$ of the lake volume drained) (Fig. 12). However, the complete drainage of moraine-dammed lakes is uncommon.

The risk from GLOFs remains low in spite of the large number of glacial lakes existing in the Baker Basin, with 28 lakes having high or very high outburst susceptibility. This is because the population and infrastructure threatened by outburst floods is scarce, since the region is mostly uninhabited (Fig. 13). Debris flows are the most damaging process triggered by the sudden drainage of glacial lakes since they can

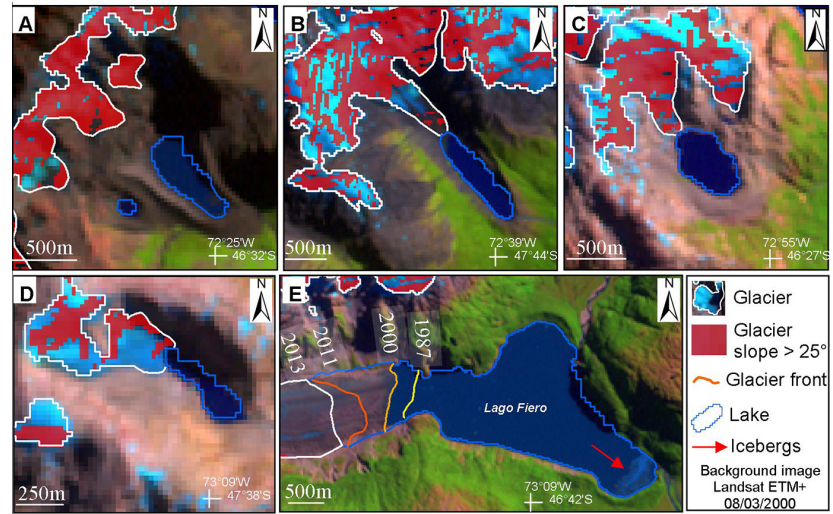

Figure 11. Examples of lakes classified with high or very high outburst susceptibility. Steep glaciers, moraines and rock-slopes surround small and medium-sized lakes. Large growing lakes are in contact with retreating glaciers and have vegetated dams (panel E). Icebergs are common in proglacial lakes in contact with grounded glaciers.

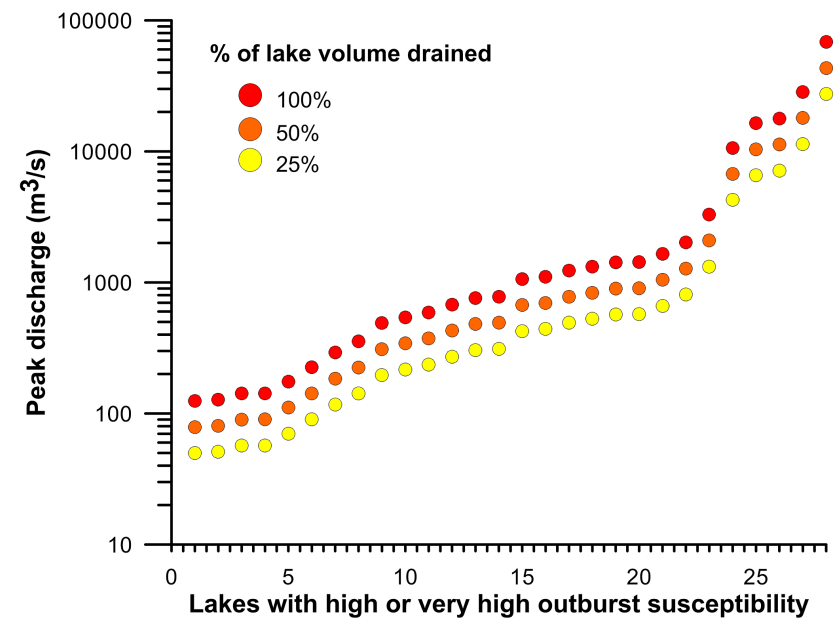

Figure 12. Potential peak discharge of GLOFs from lakes with high or very high outburst susceptibility in the Baker Basin.

develop high-impact pressures, can obstruct rivers causing back water flooding or floods from the sudden drainage of these ephemeral lakes. However, not all outburst floods can develop into debris flows, as they depend on sediment availability, channel morphology and slope gradient.

We modelled debris flow paths from the 28 morainedammed lakes with higher outburst susceptibility in the Baker Basin (using the MSF model described in Sect. 2.4.2, and setting as a source zone the lake area and as stopping condition an angle of reach of $10^{\circ}$ ) and none of them reached currently inhabited zones (Fig. 14). However, flood waves travel larger distances and could potentially flood forest and agricultural lands, damaging local inhabitants' livelihoods (Table 5). Floods can also affect transport routes isolat- 


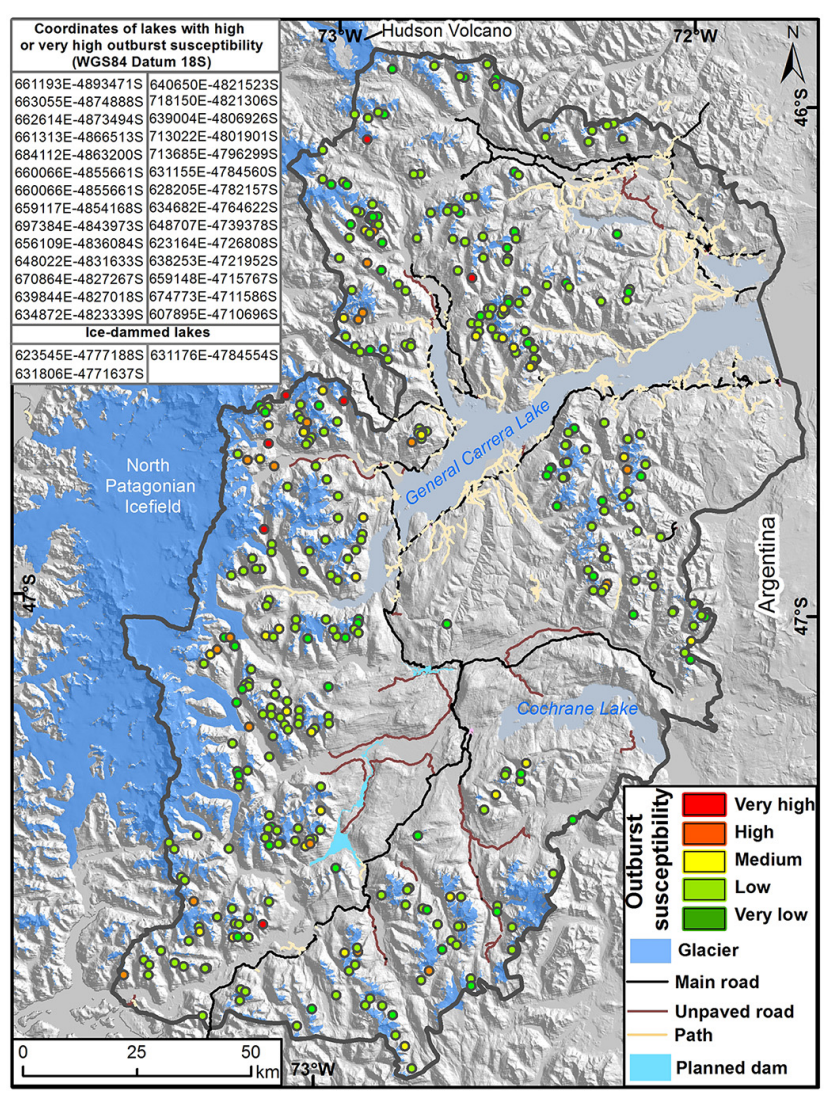

Figure 13. Classification of lake outburst susceptibility in the Baker Basin. Note that most of the lakes with high or very high outburst susceptibility are located on the west side of the basin.

ing populated areas, as has been demonstrated by historical events (Hauser, 2000; Worni et al., 2012).

\section{Discussion}

\subsection{Documented outburst floods from moraine-dammed lakes in Patagonia}

The 16 documented lakes that produced outburst floods in Patagonia are located in areas which became ice free as a consequence of 20th and early 21 th century ice retreat, and most of the lakes (13, namely $81 \%$ ) were in contact with glaciers at the time of failure. Calving-induced waves, the obstruction of the lakes outlets by icebergs, and the increase in the hydrostatic pressure over the dams as a result of lake growth/deepening may explain some of these outburst floods. The melting of ice-cored moraines also may be related to dam failures (through dam subsidence or the erosion of otherwise ice-cemented debris (Richardson and Reynolds, 2000; McKillop and Clague, 2007) since at least one of the failed moraine-dammed lakes in Patagonia had an ice-core (Worni et al., 2012). Other recently formed dams, close to glacier fronts, may also contain buried ice. Thus, most of the out- burst floods may be an expression of the adjustment of the landscape to new and evolving glacial conditions after LIA (Clague and Evans, 2000).

Most of the failed lakes had steep $\left(\geq 15^{\circ}\right)$ dam outlet slopes. The higher shear stress in these steep slopes probably favoured the dam's erosion when overflows or an increase in the lake discharge occurred. The four largest dams ( $\geq 50 \mathrm{~m}$ in height) were covered by mature forest at the time of failure. However, the vegetation could not stop the progressive erosion of these steep dams and subsequent catastrophic lake drainages. In fact, trees were incorporated in the flow increasing its damaging capacity. The largest dams had narrow fronts, closely resembling classic examples of failed moraine-dammed lakes worldwide (e.g. Lliboutry et al., 1977). These lakes could be identified as potentially hazardous through a quick examination of aerial photographs or satellite images. However, two small failed lakes had low dams with flat and broad surfaces and superficially appeared stable. A possible factor contributing to their failure is that lower dams can be easily overtopped by waves or a rise in lake level since they have less potential freeboard (i.e. there is less height difference between the lake surface and the lowest point of the dam).

All the failed lakes were located in areas prone to mass movements but only one outburst flood was certainly caused by this phenomenon (Harrison et al., 2006). The dimensions of impact waves, and hence the likelihood of a dam overtopping, are directly related to the volume and velocity of the mass movements and the lake bathymetry (Walder et al., 2003). Large and high-velocity mass movements are more likely to trigger outburst floods (Walder et al., 2003). Mass movement modelling shows that lakes in Patagonia are exposed to this phenomenon. However, frequent lowmagnitude rock-falls, debris flows or snow avalanches are probably not capable of generating large-impact waves, dam overtopping, and catastrophic lake drainage.

There is evidence of just one outburst flood that might have been triggered by an ice avalanche. However, ice avalanche modelling shows that several failed lakes were located in areas prone to ice avalanching. The deposits of ice avalanches can be rapidly obliterated hampering their identification after few months or years (Kellerer-Pirklbauer et al., 2012). Thus, this process cannot be discarded as one of the triggers of other outburst floods. The failure of lakes as a consequence of an upstream outburst is another potential cause of large floods (Xin et al., 2008). However, none of the failed lakes in Patagonia is known to have occurred by this mechanism. Large lakes $\left(>0.5 \mathrm{~km}^{2}\right)$ in areas of low relief are common in Patagonia and may delay or attenuate outburst floods as has been demonstrated in the Cachet 2 events (Dussaillant et al., 2009). Therefore, chain lake ruptures may be restricted to smaller lakes in high-relief catchment heads which show quick responses to large and rapid water influxes.

Only two lakes were completely emptied by outburst floods. This is because moraine dams generally impound 
Table 5. Potential damages caused by debris flows and floods originated from moraine-dammed lakes with high or very high outburst susceptibility in the Baker Basin.

\begin{tabular}{lrrr} 
& Routes $(\mathrm{m})$ & Others & $\begin{array}{r}\text { Forest and } \\
\text { bush }\left(\mathrm{km}^{2}\right)\end{array}$ \\
\hline $\begin{array}{l}\text { Debris flow } \\
\left.\text { (angle of reach } 10^{\circ}\right)\end{array}$ & $\begin{array}{r}- \text { Vehicle track } \\
=300 \quad \text { Foot } \\
\text { paths }=1600\end{array}$ & $\begin{array}{r}\text { - Mining camp (disused) } \\
-1 \text { Bridge }-1 \text { planned dam }\end{array}$ \\
\hline $\begin{array}{l}\text { Flood }(\text { angle } \\
\left.\text { of reach } 5^{\circ}\right)\end{array}$ & $\begin{array}{r}\text { - Route 7 } \\
1000-\text { Vehicle } \\
\text { track }=300\end{array}$ & $\begin{array}{r}\text { - 1 Bridge in } \\
\text { secondary route - }\end{array}$ & 1.3 \\
\hline
\end{tabular}

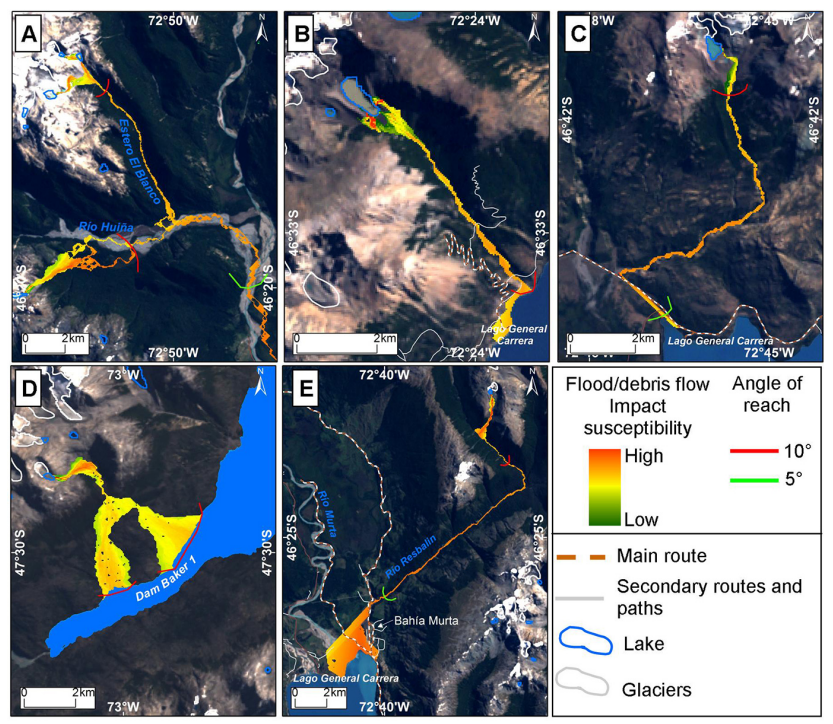

Figure 14. GLOF modelling from lakes with high or very high outburst susceptibility closest to inhabited zones. Forestry land, routes and a planned dam are in the path of potential debris flows (angle of reach $\geq 10^{\circ}$ ) and floods. The flow width in D is probably exaggerated in its unchannelized path.

only part of the lake's water volume (the rest of the water occurs below the moraine base in overdeepened valleys). Hence, in spite of the existence of lakes of hundreds of metres in depth in Patagonia (see e.g. Warren et al., 2001), complete lake drainage is unlikely.

Failed moraine-dammed lakes in Patagonia ranged in area from 0.01 to $1.82 \mathrm{~km}^{2}$. Although larger lakes exist, they have not failed in historic time. A probable explanation for the failure of these, comparatively, smaller lakes is that the area and volume of small lakes can grow quickly after small glacier changes, dramatically altering the catchment hydrology. Furthermore, large lake systems have had longer periods of adjustment (e.g. development of large low-gradient outlets) to new climatic, glacial and hydrologic conditions since most of the large lakes were formed during or before the LIA. This adjustment may have included prehistoric outburst floods that helped to shape lower and wider outlets.

\subsection{Outburst susceptibility classification}

Here we have carried out the first systematic analysis of the conditioning and triggering factors of outburst floods from moraine-dammed lakes in Patagonia. We weighted these factors (using the AHP method) to define outburst susceptibility classes. In conjunction, these data were used to develop a methodological scheme to assess the outburst susceptibility of glacier lakes in Patagonia. The approach builds on similar analyses (e.g. Bolch et al., 2011), however, the weighting of the outburst factors was based on empirical data from past outburst floods in Patagonia and thus is representative of the Patagonian geographical context. Thus, it can be used as a first-order approach to identify hazardous lakes in this region.

Twelve $(75 \%)$ of the 16 failed lakes in Patagonia had scores $\geq 65$ (other failed lakes had scores ranging from 30 to 49) and thus we selected this score to identify lakes with high outburst susceptibility. This score does not comprise all the failed lakes in Patagonia but includes lakes with at least three characteristics that make them susceptible to failure. The suggested approach, however, has drawbacks - for example, the omission of dam characteristics in the analysis and the subjectivity of the weighting scheme. Furthermore, the rapid nature of glacier changes in Patagonia (see Davies and Glasser, 2012) means that this analysis needs to be updated regularly.

The use of medium-resolution $(15-30 \mathrm{~m})$ satellite images and DEMs limit the inclusion of dam characteristics that can be critical to explain outburst floods, such as dam freeboard and resistance to erosion. However, these resources allow a rapid extraction of data from hundreds of lakes in a short time. The relatively coarse spatial resolution of the imagery means that distinguishing between lakes dammed by moraines and bedrock was not straightforward in all cases. In some examples, categorical identification of features is not even possible using finer-resolution satellite images and aerial photographs. Thus, detailed local-scale analyses of the 


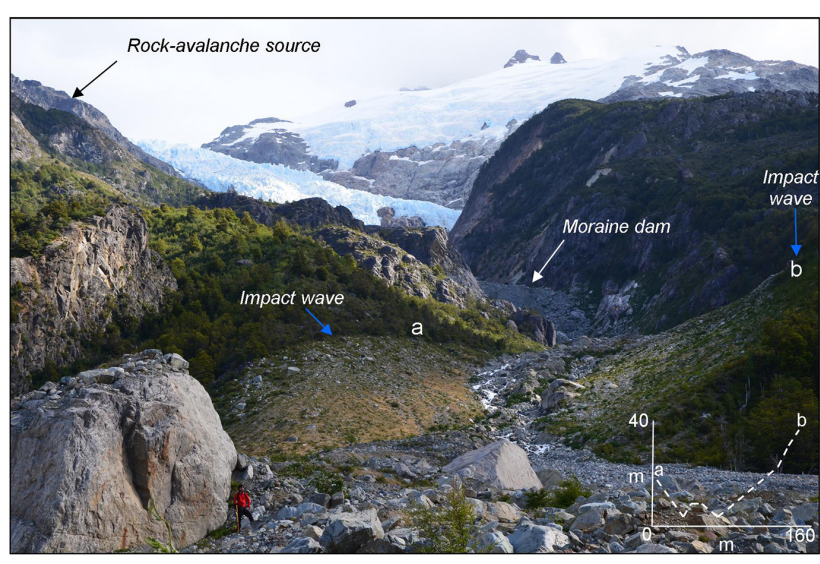

Figure 15. Geomorphic effects of an outburst flood (Los Leones Valley) produced by the impact of a rock avalanche. The small lake, detached from the glacier tongue at the time of failure, was classified with low outburst susceptibility in spite of the steep outlet slope. Note the elevated traces $(\sim 40 \mathrm{~m})$ of the impact wave and the large boulders ( $>6 \mathrm{~m}$ in diameter) transported by the flow.

lakes classified with high or very high outburst susceptibility needs to be carried out to judge whether outburst preventive or mitigation measures are required. The identification of potential source of mass movements (slope steepness and vegetation coverage) can be refined using empirical data from landslide inventories in glacial and periglacial belts in Patagonia, or geomorphic features such as fresh scars and landslide deposits.

Although the weighting scheme used in the Baker Basin is subjective, it has the advantage of being based on GLOFs conditioning and triggering factors in Patagonia. It is thus better suited to the identification of potentially hazardous lakes in this region than approaches developed for other geographical contexts. Furthermore, the evaluation of the consistency of the judgments in the weighting scheme (Table 3) is an advantage of the AHP method in relation to other qualitative or semi-quantitative approaches used in GLOF hazard assessments (see Emmer and Vilímek, 2013, for a review).

Glacier fluctuations can shift the source area of ice avalanches and expand or generate new glacial lakes, resulting in a change in outburst susceptibility and hazard over time (Huggel et al., 2001, 2004). This makes periodic monitoring of glaciers, lakes and their surroundings necessary in Patagonia, particularly near inhabited areas or critical infrastructure. The rapid growth of the Olvidado Lake three years before the outburst in 2003 is an example of the speed at which glacier and lake changes can occur in this region (Rivera and Casassa, 2004).

In the Baker Basin 28 lakes were classified with high or very high outburst susceptibility. Most of the lakes are located in uninhabited valleys or dozens of kilometres from settlements or infrastructure. However, modelled debris flows and floods from hazardous lakes reached forestry land, a planned dam, and transportation routes. Damage to access routes by GLOFs can increase accessibility problems faced by Patagonian settlements (Muñoz et al., 2006). These 28 lakes, based on the results of this study, are more susceptible to failure than other lakes. However, this does not imply that other lakes cannot also fail. For example, large, albeit infrequent, landslides or ice avalanches can cause the sudden drainage of otherwise stable lakes (Fig. 15).

The approach used in this study has the advantage that can be applied at regional-scale using publicly available satellite images and DEMs allowing the analysis of hundreds of lakes in an inexpensive way. Also, it is based on simple and robust image classification and flow modelling techniques proven in different geographical settings (Paul et al., 2002; Huggel et al., 2003; Frey et al., 2010b; Bolch et al., 2011). Thus, it is suitable for identifying the lakes most susceptible to fail in Patagonia as a first approach to GLOF hazard assessments.

\section{Conclusions}

We analysed 16 historic outburst floods from morainedammed lakes in Patagonia and our analysis shows that lakes in contact with glaciers and having moderate $\left(\geq 8^{\circ}\right)$ to steep $\left(\geq 15^{\circ}\right)$ outlet slopes are more likely to fail. The influence of other factors, such as dam height and vegetation coverage, on the lake outburst susceptibility is less clear. The dam geometry and vegetation coverage, however, had a direct influence on the flow hydrology (e.g. peak discharge and debris transport) and hence the damage potential of flows. GLOF paths in Patagonia display a rapid decrease in damage potential downstream of the lakes. Most of the steep path slopes favouring debris flow occurrence and fast flows (the most damaging processes linked with GLOFs) were at distances $\leq 3000 \mathrm{~m}$ from failed dams. However, as has been demonstrated by historical events, attenuated flows might still endanger widespread areas in unconfined valleys. Furthermore, wood transport has been common during GLOFs and can affect distant zones.

The characteristics of failed lakes in Patagonia were used to develop an outburst susceptibility scheme (based on the AHP method and remote sensing and GIS techniques) which was applied in the Baker Basin, Chilean Patagonia. The scheme allowed categorizing the outburst susceptibility of hundreds of lakes in a short time in a qualitative, yet reproducible way. The scheme integrated data from past GLOFs in Patagonia making it suitable for wider application in the region. The scheme might be used to complement GLOF hazard assessments in Patagonia which until now have relied mostly on statistical analysis of short-term series of flood data. The identification of the lakes more susceptible to failure, and the empirical modelling of the floods, are first steps toward a full GLOF hazard assessment which should ultimately include data on potential flood intensity (e.g. flood 
volume, velocity and sediment entrainment/deposition) and GLOF probability in a determined time span.

Acknowledgements. We thank Rodrigo Iribarren for assistance in the field. This work was improved by the constructive reviews of Martin Mergili, Adam Emmer and an anonymous reviewer, and by the comments of the Editor Paolo Tarolli. Michael Crozier is also thanked for his comments on an earlier draft of this paper. P. Iribarren Anacona is a Becas Chile fellow.

Edited by: P. Tarolli

Reviewed by: M. Mergili, A. Emmer, and one anonymous referee

\section{References}

Alean, J.: Ice avalanches: some empirical information about their formation and reach, J. Glaciol., 31, 324-333, 1985.

Allen, S. K., Schneider, D., and Owens, I. F.: First approaches towards modelling glacial hazards in the Mount Cook region of New Zealand's Southern Alps, Nat. Hazards Earth Syst. Sci., 9, 481-499, doi:10.5194/nhess-9-481-2009, 2009.

Andreassen, L. M., Paul, F., Kääb, A., and Hausberg, J. E.: Landsatderived glacier inventory for Jotunheimen, Norway, and deduced glacier changes since the 1930s, The Cryosphere, 2, 131-145, doi:10.5194/tc-2-131-2008, 2008.

Ayalew, L., Yamagishi, H., Marui, H., and Kanno, T.: Landslides in Sado Island of Japan: Part II. GIS-based susceptibility mapping with comparisons of results from two methods and veri?cations, Eng. Geol., 81, 432-445, 2005.

Bajracharya, B., Shrestha, A. B., and Rajbhandari, L.: Glacial lake outburst floods in the Sagarmatha region, Mountain Res. Develop., 27, 336-344, 2007.

Barrientos, S.: Earthquakes in Chile, in: The Geology of Chile, edited by: Moreno, T. and Gibbons, W. Geological Society of London, 263-287, 2007.

Bolch, T., Peters, J., Yegorov, A., Pradhan, B., Buchroithner, M. F., and Blagoveshchensky, V.: Identification of potentially dangerous glacial lakes in the northern Tien Shan, Nat. Hazards, 59, 1691-1714, 2011.

Buchroithner, M. F., Jentsch, G., and Waniverhaus, B.: Monitoring of Recent Geological Events in the Khumbu Area (Himalaya, Nepal) by Digital Processing of Landsat MSS data, Rock Mechan., 15, 181-197, 1982.

Breien, H., De Blasio, F. V., Elverhøi, A., and Høeg, K.: Erosion and morphology of a debris flow caused by a glacial lake outburst flood, Western Norway, Landslides 5, 271-280, 2008.

Clague, J. J. and Evans, S. G.: A review of catastrophic drainage of moraine-dammed lakes in British Columbia, Quaternary Sci. Rev., 19, 1763-1783, 2000.

Costa, J. E. Schuster, R.L.: The formation and failure of natural dams, Geol. Soc. Am. Bull., 100, 1054-1068, 1988.

Davies, B. J. and Glasser, N. F.: Accelerating recession in Patagonian glaciers from the "Little Ice Age" (c. AD 1870) to 2011, J. Glaciol., 58, 1063-1084, 2012.

Diaz, M., Pedrozo, F., Reynolds, C. S., and Temporettia, P.: Chemical composition and the nitrogen-regulated trophic state of Patagonian lakes, Limnologica, 37, 17-27, 2007.
Dussaillant, A., Benito, G., Buytaert, W., Carling, P., Meier, C., and Espinoza, F.: Repeated glacial-lake outburst floods in Patagonia: an increasing hazard?, Nat. Hazards, 54, 469-481, 2009.

El Diario de Aysén.: Perecen ahogados 4 pobladores en Caleta Tortel, 12 January 1977 a.

El Diario de Aysén.: Avalancha de agua provocó la tragedia, 13 January $1977 b$.

El Diario de Aysén.: Auxilian a pobladores en Murta, 14 March 1977c.

Emmer, A. and Cochachin, A.: The causes and mechanisms of moraine-dammed lake failures in the Cordillera Blanca, North American Cordillera, and Himalayas, AUC Geographica, 48, 515, 2013.

Emmer, A. and Vilímek, V.: Review Article: Lake and breach hazard assessment for moraine-dammed lakes: an example from the Cordillera Blanca (Peru), Nat. Hazards Earth Syst. Sci., 13, 1551-1565, doi:10.5194/nhess-13-1551-2013, 2013.

Fujita, K., Sakai, A., Takenaka, S., Nuimura, T., Surazakov, A. B., Sawagaki, T., and Yamanokuchi, T.: Potential flood volume of Himalayan glacial lakes, Nat. Hazards Earth Syst. Sci., 13, 18271839, doi:10.5194/nhess-13-1827-2013, 2013.

Frey, H., Haeberli, W., Linsbauer, A., Huggel, C., and Paul, F.: A multi-level strategy for anticipating future glacier lake formation and associated hazard potentials, Nat. Hazards Earth Syst. Sci., 10, 339-352, doi:10.5194/nhess-10-339-2010, 2010a.

Frey, H., Huggel, C., Paul, F., and Haeberli, W.: Automated detection of glacier lakes based on remote sensing in view of assessing associated hazard potentials, in: Proceedings of the 10th Internatinal Symposium on High Mountain Remote Sensing Cartography, edited by: Kaufmann, V. and Sulzer, W., Grazer Schriften der Geographie und Raumforschung, 45, 261-272, $2010 \mathrm{~b}$.

Glasser, N. F., Harrison, S., Jansson, K. N., Anderson, K., and Cowley, A.: Global sea-level contribution from the Patagonian Icefields since the Little Ice Age maximum, Nat. Geosci., 4, 303307, 2011.

Glasser, N. F. and Jansson, K. N.: The glacial map of southern South America, J. Maps, 2008, 175-196, 2008.

Grove, M.: Glacier fluctuations and hazards, Geogr. J., 153, 351369, 1987.

Gruber, S., Huggel, C., and Pike, R.: Modelling mass movements and landslide susceptibility using geomorphometry, in: Geomorphometry: Geomorphometry: Concepts, Software, Applications, edited by: Hengl, T. and Reuter, H. I., Developments in Soil Science, Vol. 33, Elsevier B.V. ISSN 0166-2481, doi:10.1016/S0166-2481(08)00023-8, 2008.

Gruber, S. and Peckham, S.: Land surface parameters and objects specfic to hydrology, in: Hengl, T. and Reuter, H. I., Geomorphometry: Geomorphometry: Concepts, Software, Applications. Developments in Soil Science, Vol. 33, Elsevier B.V. ISSN 01662481, doi:10.1016/S0166-2481(08)00007-X, 2008.

Hauser, A.: Remociones en masa en Chile. Second ed. Boletín No. 59. Servicio Nacional de Geología y Minería, Santiago, p. 89, 2000, 1993.

Harrison, S.: Patagonia, edited by: Singh, V. P., Singh, P., and Haritashya, U. K., in: Encyclopedia of Snow, Ice and Glaciers, 824826, Springer-Verlag, Dordrecht, 2011.

Harrison, S., Glasser, N., Winchester, V., Haresign, E., Warren, C. R., and Jansson, K.: A glacial lake outburst flood associated with 
recent mountain glacier retreat, Patagonian Andes, Holocene, 16, 611-620, 2006.

Hewitt, K.: Natural dams and outburst floods in the Karakorum Himalaya, in: hydrological Aspects of Alpine and High-mountain Areas, edited by: Glen, J. W., International Association of Hydrological Sciences (IAHS) 138, IAHS Press: Wallingford; 259269,1982

Hijmans, R. J., Cameron, S. E., Parra, J. L., Jones, P. G., and Jarvis, A.: Very high resolution interpolated climate surfaces for global land areas, Int. J. Climatol., 25, 1965-1978, 2005.

Hubbard, B., Heald, A., Reynolds, J. M., Quincey, D., Richardson, S. D., Zapata, M. L., Santillan, N. P., and Hambrey, M. J.: Impact of a rock avalanche on a moraine-dammed proglacial lake: Laguna Safuna Alta, Cordillera Blanca, Peru, Earth Surf. Proc. Landf., 30, 1251-1264, 2005.

Huggel, C., Kääb, A., Haeberli, W., Teysseire, P., and Paul, F.: Remote sensing based assessment of hazards from glacier lake outbursts: a case study in the Swiss Alps, Can. Geotech. J., 39, 316330, 2002

Huggel, C., Kääb, A., Haeberli, W., and Krummenacher, B.: Regional-scale GIS-models for assessment of hazards from glacier lake outbursts: evaluation and application in the Swiss Alps, Nat. Hazards Earth Syst. Sci., 3, 647-662, doi:10.5194/nhess-3-647-2003, 2003.

Huggel, C., Haeberli, W., Kääb, A., Bieri, D., and Richardson, F.: An assessment procedure for glacial hazards in the Swiss Alps, Can. Geotech. J., 41, 1068-1083, 2004.

Hungr, O., Morgan, G. C., and Kellerhals, P.: Quantitative analysis of debris hazards for design of remedial measures, Can. Geotech. J., 21, 663-677, 1984.

Hsu, K. J.: Catastrophic debris streams (Sulzstroms) generated by rockfalls, Geol. Soc. Am. Bull., 86, 129-140, 1975.

HidroAysén.: Estudio de Impacto Ambiental Proyecto HidroAysén, available at: http://www.e-seia.cl (last access: 5 July 2014), 2008.

Iribarren Anacona, P., Mackintosh, A., and Norton, K. P.: Hazardous processes and events from glacier and permafrost areas: lessons from the Chilean and Argentinean Andes, Earth Surf. Process. Landf., (State of Science Paper), doi:10.1002/esp.3524, 2014.

Kääb, A., Huggel, C., Fischer, L., Guex, S., Paul, F., Roer, I., Salzmann, N., Schlaefli, S., Schmutz, K., Schneider, D., Strozzi, T., and Weidmann, Y.: Remote sensing of glacier- and permafrostrelated hazards in high mountains: an overview, Nat. Hazards Earth Syst. Sci., 5, 527-554, doi:10.5194/nhess-5-527-2005, 2005.

Kellerer-Pirklbauer, A., Slupetzky, H., and Avian, M.: Iceavalanche impact landforms: The event in 2003 at the glacier Nördliches Bockkarkees, Hohe Tauern Range, Austria, Geograf. Annal. A, Phys. Geogr., 94, 97-115, doi:10.1111/j.14680459.2011.00446.x, 2012.

Lari, S., Frattini, P., and Crosta, G. B.: Integration of natural and technological risks in Lombardy, Italy, Nat. Hazards Earth Syst. Sci., 9, 2085-2106, doi:10.5194/nhess-9-2085-2009, 2009.

Lliboutry, L., Arnao, B. M., Pautre, A., and Schneider, B.: Glaciological problems set by the control of dangerous lakes in Cordillera Blanca, Peru. I. Historical failures of morainic dams, their causes and prevention, J. Glaciol., 18, 239-254, 1977.
Loriaux, T. H. and Casassa, G.: Evolution of glacial lakes from the Northern Patagonian Icefield and terrestrial water storage in a sea-level rise context, Global Planet. Change, 102, 33-40, 2013.

Masiokas, M. H., Rivera, A., Espizúa, L. E., Villalba, R., Delgado, S., and Aravena, J. C.: Glacier fluctuations in extratropical South America during the past 1000 years, Palaeogeogr. Palaeoclim. Palaeoecol., 281, 242-268, 2009.

Masiokas, M. H., Luckman, B. H., Villalba, R., Delgado, S., Skvarca, P., and Ripalta, A.: Little Ice Age fluctuations of small glaciers in the Monte Fitz Roy and Lago del Desierto areas, south Patagonian Andes, Argentina, Palaeogeogr. Palaeoclim. Palaeoecol., 281, 351-362, 2009.

McKillop, R. J. and Clague, J. J.: Statistical, remote sensing-based approach for estimating the probability of catastrophic drainage from moraine-dammed lakes in southwestern British Columbia, Global Planet. Change, 56, 153-171, 2007.

Mergili, M. and Schneider, J. F.: Regional-scale analysis of lake outburst hazards in the southwestern Pamir, Tajikistan, based on remote sensing and GIS, Nat. Hazards Earth Syst. Sci., 11, 1447 1462, doi:10.5194/nhess-11-1447-2011, 2011.

Muñoz, M., Pérez, L., Sanhueza, R., Urrutia, R., and Rovira, A.: Los paisajes del agua en la cuenca del Río Baker: bases conceptuales para su valoración integral, Rev. Geogr.Norte Grande, 36, 31-48, 2006.

USGS, NASA., and LANDSAT 7 SCIENCE TEAM: Preliminary assessment of the value of Landsat $7 \mathrm{ETM}+$ data following Scan Line Corrector malfunction.2003, available at: http://landsathandbook.gsfc.nasa.gov/pdfs/SLC_off_Scientific_ Usability.pdf, 2003.

Nicoletti, P. G. and Sorriso-Valvo, M.: Geomorphic controls of the shape and mobility of rock avalanches, Geol. Soc. Am. Bull., 103, 1365-1373, 1991.

O'Connor, J. E., Hardison, J. H., and Costa, J. E.: Debris flows from failures of Neoglacial-age moraine dams in the Three Sisters and Mount Jefferson Wilderness areas, Oregon, US Geological Survey, Reston (Virginia), 93 pp., 2001.

Paul, F., Kääb, A., Maisch, M., Kellenberger, T., and Haeberli, W.: The new remote sensing derived Swiss glacier inventory: I. Methods, Ann. Glaciol., 34, 355-361, 2002.

Peduzzi, P.: Landslides and vegetation cover in the 2005 North Pakistan earthquake: a GIS and statistical quantitative approach, Nat Hazards Earth Syst. Sci., 10, 623-640, doi:10.5194/nhess-10623-2010, 2010.

Reuter, H. I. and Nelson, A.: Geomorphometry in ESRI packages, edited by: Hengl, T. and Reuter, H. I., Geomorphometry: Geomorphometry: Concepts, Software, Applications, Developments in Soil Science 269-291 Elsevier B.V., ISSN 0166-2481, 2008.

Reynolds, J. M., Dolecki, A., and Portocarrero, C.: Construction of a drainage tunnel as part of glacial lake hazard mitigation at Hualcán, Cordillera Blanca, Peru, in: Geohazards in EngineeringGeology, edited by: Maund, J. G. and Eddleston. M., Geological Society Special Publication (London), No. 15. Geological Society of London, London, 41-48,1998.

Richardson, S. D. and Reynolds, J. M.: An overview of glacial hazards in the Himalayas, Quaternary Int., 65/66, 31-47, 2000a.

Richardson, S. D. and Reynolds, J. M.: Degradation of ice-cored moraine dams: implications for hazard development, in: DebrisCovered Glaciers (Proceedings of a workshop held at Seattle, 
Washington, USA, September 2000), The Netherlands 187-197, 2000b.

Rivera, A. and Casassa, G.: Ice elevation, areal, and frontal changes of glaciers from National Park Torres del Paine, Southern Patagonia Icefiled, Artic Antarct. Alpine Res., 36, 379-389, 2004.

Saaty, T. L.: The Analytic Hierarchy Process: Planning, Priority Setting, Resource Allocation, ISBN 0-07-054371-2, McGraw-Hill, 1980.

Saaty, T. L. and Vargas, L. G.: Models, Methods, Concepts and Applications of the Analytic Hierarchy Process, Kluwer, Dordrecht, 2001.

Slingerland, R. L. and Voight, B.: Occurrences, properties and predictive models of landslide-generated impulse waves. Rockslides and avalanches, Vol. 2, edited by: Voight, B., Elsevier, Amsterdam, 317-397, 1979.

Svoboda, F. and Paul, F.: A new glacier inventory on southern Baffin Island, Canada, from ASTER data: I. Applied methods, challenges and solutions, Ann. Glacio., 50, 11-21, 2009.

Tachikawa, T., Kaku, M., Iwasaki, A., Gesch, D., Oimoen, M., Zhang, Z., Danielson, J.,Krieger, T., Curtis, B., Haase, J., Abrams, M., Crippen, R., and Carabajal, C.: ASTER Global Digital Elevation Model Version 2-Summary of Validation Results, The NASA Land Processes Distributed Active Archive Center and the Joint Japan - US ASTER Science 5 Team, available at: https://lpdaacaster.cr.usgs.gov/GDEM/Summary_ GDEM2_validation_report_final.pdf (last access: 12 February 2014), 2011.

Tweed, F. S. and Russell, A. J.: Controls on the formation and sudden drainage of glacier-impounded lakes: implications for jökulhlaup characteristics, Progr. Phys. Geogr., 23, 79-110, 1999.
Villalba, R., Leiva, J. C., Rubullis, S., Suarez, J., and Lenzano, L.: Climate, Tree-Ring, and Glacial Fluctuations in the Río Frías Valley, Rio Negro, Argentina, Arct. Alpine Res., 22, 215-232, 1990.

Vince, G.: Dams for Patagonia. Newsfocus, Science, 329, 382-385, 2010.

Wahl, T.: Uncertainty of Predictions of Embankment Dam Breach Parameters, J. Hydraul. Eng., 130, 389-397, 2004.

Walder, J. S. and O'Connor, J. E.: Methods for predicting peak discharge of floods caused by failure of natural and constructed earthen dams, Water Resour. Res., 3, 2337-2348, 1997.

Walder, J. S., Watts, P., Sorensen, O. E., and Janssen, K.: Tsunamis generated by subaerial mass flows, J. Geophys. Res., 108, 22362255, 2003.

Wang, W., Yao, T., Gao, Y., Yang, X., and Kattel, D.B.: A first- order method to identify potentially dangerous glacial lakes in a region of the southeastern Tibetan Plateau, Mountain Res. Develop., 31, 122-130, 2011.

Warren, C., Benn, D., Winchester, V., and Harrison, S.: Buoyancy driven lacustrine calving, Glaciar Nef, Chilean Patagonia, J. Glaciol., 47, 135-146, 2001.

Worni, R., Stoffel, M., Huggel, C., Volz, C., Casteller, A., and Luckman, B.: Analysis and dynamic modeling of a moraine failure and glacier lake outburst flood at Ventisquero Negro, Patagonian Andes (Argentina), J. Hydrol., 444/445, 134-145, 2012.

Xin, W., Shiyin, L., Wanqin, G., and Junli, X.: Assessment and simulation of glacier lake outburst floods for Longbasaba and Pida Lakes, China. Mt. Res. Dev., 28, 310-317, 2008. 